\title{
Human Health Risk Assessment through Roasted Meats Consumption
}

\author{
Luana C. S. Leite ${ }^{1}$, Elaine S. de P. Melo ${ }^{1}$, Daniela G. Arakaki ${ }^{1}{ }^{(\mathbb{D}}$, Elisvânia F. dos Santos ${ }^{2,3}{ }^{(1)}$ and \\ Valter A. do Nascimento $1, *$ [D \\ 1 Group of Spectroscopy and Bioinformatics Applied to Biodiversity and Health, School of Medicine, \\ Postgraduation Program in Health and Development in the Midwest Region, Faculty of Medicine, \\ Federal University of Mato Grosso do Sul, Campo Grande MS 79079-900, Brazil; \\ luanacarolinasl@gmail.com (L.C.S.L.); elainespmelo@hotmail.com (E.S.d.P.M.); \\ daniarakaki@gmail.com (D.G.A.) \\ 2 Faculty of Pharmaceutical Sciences, Food, and Nutrition, Federal University of Mato Grosso do Sul-UFMS, \\ Campo Grande MS 79079-900, Brazil; elisvania@gmail.com \\ 3 Postgraduation Program in Health and Development in the Midwest Region, Faculty of Medicine, \\ Federal University of Mato Grosso do Sul, Campo Grande MS 79079-900, Brazil \\ * Correspondence: aragao60@hotmail.com
}

Received: 10 August 2020; Accepted: 10 September 2020; Published: 16 September 2020

\begin{abstract}
Data on the content of metals and metalloids in roasted meats with different types of wood and charcoal are still scarce in the literature. The concentrations of metals (Al, Cr, Cd, Cu, Fe, Mg, Mn, Mo, Ni, V, and $\mathrm{Zn}$ ) and metalloid (As) were determined by inductively coupled plasma mass spectrometry (ICP-OES) after microwave digestion, and the estimated daily intake $(E D I)$ for adults was assessed to determine the hazard quotient $(H Q)$. The concentrations of $\mathrm{Al}, \mathrm{Cr}, \mathrm{Cu}$, and $\mathrm{Fe}$ in raw meats were below the data obtained in other countries. The concentration of As $(0.17 \pm 0.42-0.23 \pm 0.10 \mathrm{mg} / \mathrm{kg}), \mathrm{Mg}(206.77 \pm 3.99-291.95 \pm 8.87 \mathrm{mg} / \mathrm{kg})$, $\mathrm{V}(0.42 \pm 0.14-6.66 \pm 0.80 \mathrm{mg} / \mathrm{kg})$, and $\mathrm{Zn}(6.66 \pm 0.80-48.13 \pm 0.56 \mathrm{mg} / \mathrm{kg})$ in raw meats exceeded the values in the literature. The concentrations of $\mathrm{Mg}, \mathrm{As}, \mathrm{Cr}, \mathrm{Fe}, \mathrm{V}$, and $\mathrm{Zn}$ are high when the meat is roasted using wood. All levels of $\mathrm{Al}, \mathrm{As}, \mathrm{Cr}, \mathrm{Cu}, \mathrm{Fe}, \mathrm{Mg}, \mathrm{Mn}, \mathrm{Mo}, \mathrm{V}$, and $\mathrm{Zn}$ in raw meats are lower than those of meat roasted with coal and wood. The content of As in meat roasted with Chromed Copper Arsenate (CCA) wood $(15.10 \pm 0.27-26.25 \pm 1.47 \mathrm{mg} / \mathrm{kg})$ is higher than meat roasted with charcoal $(0.46 \pm 0.09-1.16 \pm 0.50 \mathrm{mg} / \mathrm{kg})$. EDI and $H Q$ values revealed a minimal exposure of the adult population to those metals through roasted-meats consumption. However, EDI values of As in some roasted meats are above standard limits. Roast meats with wood showed higher levels of major and trace elements than meats roasted with coal. High exposures, in the long-term, may cause damage to health.
\end{abstract}

Keywords: toxic metals; chronic daily intake; human health risk assessment; ICP-OES; arsenic

\section{Introduction}

According to the Food and Agriculture Organization (FAO) of the United Nations, the primary sources of meat are domesticated animal species, such as cattle, pigs, birds, sheep, and goats, respectively [1]. The content of major elements ( $\mathrm{Ca}, \mathrm{Fe}, \mathrm{Mg}, \mathrm{K}, \mathrm{Na}$, and $\mathrm{P}$ ) and trace elements ( $\mathrm{Zn}, \mathrm{Mn}$, $\mathrm{Cu}, \mathrm{As}, \mathrm{Cd}, \mathrm{Hg}, \mathrm{Pb}$, and $\mathrm{Se}$ ) in meats [2], lipids, carbohydrates, proteins, color, and texture depend on several aspects, such as the region in which the animal is raised, genetics, age, food, type of cut, and tissue $[3,4]$.

The Commission of the European Communities stipulated the maximum allowed limit of As, Cd, and $\mathrm{Pb}$ in poultry, cattle, pork, and sheep muscle and offal [5]. Different methods are used to determine 
the ingested amount of food contaminants, water, and other liquids. International organizations such as the Joint FAO/WHO Expert Committee on Food Additives (JECFA) and the European Food Safety Authority (EFSA) recommends the use of health-based guidance values (HBGVs) as provisional tolerable weekly intake (PTWI) and benchmark dose lower confidence limit (BMDL) for metals and metalloids considered contaminants that may accumulate in the body [6-8]. Other approaches to estimate the possible exposure to food additives from a diet comprise the estimated daily intake (EDI) [9] and the hazard quotient (HQ) method. The EDI is the amount of an additive ingested by the average consumer of the food $[10,11]$, and the $H Q$ is the ratio of the potential exposure to a substance at a level at which no adverse effects are expected, respectively [12]. Moreover, the minimal risk level (MRL) is an estimate of the daily human exposure to a hazardous substance that contains elements such as $\mathrm{Al}, \mathrm{Cd}, \mathrm{Co}, \mathrm{Cr}, \mathrm{Cu}, \mathrm{Mo}, \mathrm{V}$, and $\mathrm{Zn}$ that is likely to be without appreciable risk of adverse [13]. On the other hand, for some elements, such as $\mathrm{Cu}, \mathrm{Fe}, \mathrm{Mg}, \mathrm{Mn}, \mathrm{Mo}, \mathrm{Ni}, \mathrm{V}$, and $\mathrm{Zn}$, there is a maximum level of daily nutrient intake (UL) that aims to avoid the risks of toxicity [14].

The way meats of different types are prepared [15], and especially storage conditions and handling, are potential sources of contamination and can significantly alter the levels of metals present in food [16], by placing food in contact with the contaminants. During the thermal processing of food, reactions that change color and taste occur, including the ones that result in toxic and mutagenic substances, such as furan, acrylamide, and acrolein [17]. Besides, fuels such as coal, which is used in barbecue grills, release heavy metals [18], becoming a possible food pollutant.

According to studies, metals are an expressive route of exposure to toxic compounds [19-21]. Total and bioaccessible concentrations of trace elements ( $\mathrm{Al}, \mathrm{As}, \mathrm{Cd}, \mathrm{Cu}, \mathrm{Fe}, \mathrm{Hg}, \mathrm{Mn}, \mathrm{Ni}, \mathrm{Pb}$, and $\mathrm{Zn}$ ) were measured in charcoals from 15 barbecue products available from UK retailers [19]. According to an estimate of daily intake for the bioaccessible trace elements in the coal samples available in the United Kingdom, As and $\mathrm{Al}$ are the elements that caused the most significant concern of impact on human health [19]. The Canadian government considers charcoal as a source of hazardous emissions for health; thus, its sale and advertising are under regulation [20].

In many countries, like Brazil, Argentina, Paraguay, and Bolivia, the use of wood on a barbecue grill for roasting meat is a cultural issue. In Brazil, along with the various types of wood sold as barbecue fuels, some people use the remains of construction wood, without knowing that a number of them have undergone chemical treatment, such as Eucalyptus and other wood that is treated with Chromed Copper Arsenate (CCA) [22]. Consequently, wood smoke contains several toxic, harmful air pollutants, including As and $\mathrm{Cr}$ [23-25]. In view of the above, studies considering the EDI and comparisons with reference values for each element (PTWI, UL, BMDL, and MRL) can provide an overview of human-health-risk assessment [6-14].

Some studies reported the concentration of toxic and essential elements in several commercial types of meats, using different thermal preparation methods (roasting, boiling, and microwave cooking) [26], determination of metal in raw meats by inductively coupled plasma optical spectrometry (ICP-OES) [27] and inductively coupled plasma mass spectrometry (ICP-MS) [28], the role of detergent washing on levels of metals in meat [29], and validation of mineralization procedures for the determination of contents in raw meats samples by ICP-MS [30]. However, there is limited data on the major and trace elements composition of roast meats consumed by the public in Brazil and other countries, especially regarding the metal and metalloids content after barbecuing-smoke exposure. To date, there are no studies that have quantified the accumulation of macro- and microelements in different types of meat when roasted on barbecue grills, using different kinds of wood and charcoal as fuels. The aim of this study was (i) to determine the levels of $\mathrm{Cd}, \mathrm{Co}, \mathrm{Cr}, \mathrm{Mn}, \mathrm{Mg}, \mathrm{Cu}, \mathrm{Al}, \mathrm{Mo}, \mathrm{Ni}, \mathrm{Pb}$, $\mathrm{V}, \mathrm{Fe}, \mathrm{Zn}$, and As in beef topside, pork loin, chicken breast, and lamb shank roasted on barbecues, using different types of fuels, such as woods and charcoal; (ii) obtain the EDI and $H Q$ due to exposure to metals consumed from roasted meats, using wood and coals; and (iii) compare the EDI values in roasted meats with the values established by the PTWI, UL, BMDL, and MRL. 


\section{Materials and Methods}

\subsection{Sample Collection}

Three samples of each type of raw meat were purchased from six different butcheries of Campo Grande, MS, in the Midwest region of Brazil, while considering the different origins in terms of the production system (meat labels) and anatomical location: beef (topside), pork (loin), lamb (shank), and chicken (breast without skin).

The following woods were acquired through direct purchase in commercial establishments in Campo Grande, Brazil: Eucalyptus citriodora wood, Guazuma ulmifolia wood, Anadenanthera falcata wood, and treated Eucalyptus (CCA-treated Eucalyptus wood). Two charcoals were purchased: Eucalyptus citriodora coal and Guazuma ulmifolia coal. The purchase of wood and coals were in 2019.

\subsection{Preparation of Raw Meat Samples}

Triplicate portions of proximate to $50 \mathrm{~g}$ of each meat sample were obtained by using stainless steel scalpels, individually, to avoid contamination. All samples were ground in a domestic processor with stainless steel blades (Thermomix TM5 equipment-Vorwerk L.L.C., Wuppertal, Germany) and homogenized to secure faithful batches of each type of meat. The samples were individually placed in universal sterilized plastic collectors previously identified and stored in a freezer at $-20{ }^{\circ} \mathrm{C}$ until the time of analysis.

\subsection{Preparation of Raw Meat Samples for Barbecue Grills}

Slices proximate to $90 \mathrm{~g}$ in triplicate of three different samples of raw meat with $1.70 \mathrm{~cm}$ thickness were made, using stainless steel scalpels. Samples were divided into three groups: raw samples, samples roasted on a barbecue with wood or charcoal as fuels, and samples of hamburger roasted on an electric barbecue. The whole process of possible roasting combinations of the various meat samples on the masonry barbecue grill, using different types of wood and coals, was tested in triplicate and according to Table 1.

Table 1. Meat samples and types of fuels.

\begin{tabular}{|c|c|c|c|}
\hline \multirow{2}{*}{ Meat Sample } & \multicolumn{3}{|c|}{ Types of Fuels } \\
\hline & Biomass & & Electricity \\
\hline $\begin{array}{c}\text { Beef topside }(n=18) \\
\text { Pork loin }(n=18) \\
\text { Lamb shank }(n=18) \\
\text { Chicken breast (without skin) }(n=18)\end{array}$ & $\begin{array}{c}\text { Wood } \\
\text { Eucalyptus citriodora } \\
\text { Guazuma ulmifolia } \\
\text { Anadenanthera falcate } \\
\text { Treated Eucalyptus citriodora }\end{array}$ & $\begin{array}{c}\text { Coal } \\
\text { Eucalyptus citriodora } \\
\text { Guazuma ulmifolia }\end{array}$ & Electric barbecue grill \\
\hline
\end{tabular}

A masonry barbecue that was $60 \mathrm{~cm}$ long, 37 wide, and $31 \mathrm{~cm}$ deep was used to roast the meat. The wood or charcoal was evenly distributed inside the masonry barbecue. Meat samples were placed on a stainless steel grid, at the height of $40 \mathrm{~cm}$ from the wood or charcoal. Each sample of meat on the masonry barbecue grill remained for $30 \mathrm{~min}$ in the presence of firewood or charcoal, until roasting to the point. After the meat was roasted, samples were sliced, using a scalpel with stainless steel blades. Then, the samples were weighed and homogenized (Thermomix TM5 equipment-Vorwerk L.L.C., Wuppertal, Germany), and then stored in a universal plastic collector and frozen at $-20^{\circ} \mathrm{C}$ until analysis.

The following procedures were performed for hamburger samples roasted on an electric barbecue: Before the start of the cooking experiment, the electric barbecue grill was washed with detergent, rinsed thoroughly, and dried. Burgers of proximate to $50 \mathrm{~g}$ of four different samples of raw meat previously processed were made. The meat was heated by using an electric barbecue grill 
(Electric Barbecue Mister Grill Plus equipment-Cotherm LTDA, São Paulo, Brazil), at its maximum setting. After fifteen minutes of grilling, the meat was flipped, using a disposable plastic spoon, and grilling continued for fifteen more minutes, for a total of $30 \mathrm{~min}$ of grilling. The electric barbecue grill was switched off, and it was found that the meat was cooked in the center and roasted to the point. After the burgers were roasted, samples were sliced, using a scalpel with a stainless steel blade. Then, they were weighed, homogenized (Thermomix TM5 equipment-Vorwerk L.L.C., Wuppertal, Germany), and stored in a universal plastic collector and taken for analysis. Experiments were performed in triplicate.

\subsection{Preparation of Raw and Roasted Meat by Microwave Digestion}

A $300 \mathrm{mg}$ mass of each sample was cut with stainless steel scalpels and then weighed (raw meat and roasted meat) in the digestion vessels. We added $2 \mathrm{~mL}$ of $\mathrm{HNO}_{3}$ (65\% Merck, Darmstadt, Germany), $1.5 \mathrm{~mL}$ of $\mathrm{H}_{2} \mathrm{O}_{2}$ (30\% Merck, Darmstadt, Germany), and $2 \mathrm{~mL}$ of ultrapure deionized water $(18 \mathrm{M} \Omega \mathrm{cm}$, Milli-Q Millipore, Bedford, MA, USA) to each sample. The samples were digested in a microwave digestion system (Speedwave four ${ }^{\circledR}$, Berghof, Germany). This application used the temperature program shown in Table 2. The samples were then transferred to clean a polyethylene tube and diluted with ultrapure water to $10 \mathrm{~mL}$. All digestions were performed in triplicate for fresh and roasted meat samples and analytical blanks.

Table 2. Operating conditions for the microwave digestion system.

\begin{tabular}{cccc}
\hline \multirow{3}{*}{ Parameters } & \multicolumn{3}{c}{ Step } \\
\cline { 2 - 4 } & $\mathbf{1}$ & $\mathbf{2}$ & $\mathbf{3}$ \\
\hline Temperature $\left({ }^{\circ} \mathrm{C}\right)$ & 100 & 150 & 50 \\
Ramp time $(\mathrm{min})$ & 1 & 1 & 1 \\
Hold time $(\mathrm{min})$ & 5 & 10 & 1 \\
Power $(\mathrm{W})$ & 1160 & 1160 & 0 \\
Pressure $(\mathrm{Bar})$ & 30 & 30 & 25 \\
\hline
\end{tabular}

\subsection{Elemental Measurement by Using ICP-OES}

The determination of major and trace elements in samples of different types of raw and roasted meat was performed by using an inductively coupled plasma optical emission spectrometer (ICP-OES) with an axial view (iCAP 6300 Series, Thermo Scientific, Waltham, MA, USA). The instrumental and operating parameters for ICP-OES are shown in Table 3.

Table 3. ICP-OES instrumental parameters.

\begin{tabular}{lc}
\multicolumn{1}{c}{ Parameter } & Setting \\
\hline Sample Flush Time (s) & 30 \\
Pump Stabilization Time (s) & 5.0 \\
Nebulizer Gas Flow (L/min) & 0.7 \\
Auxiliary Gas Flow (L/min) & 0.5 \\
Flush Pump Rate (rpm) & 50 \\
RF Power (W) & 1150 \\
Analysis Pump Rate (rpm) & 50 \\
Coolant Gas Flow (L/min) & Al 167.079; As 189.042; Cd 228.802; Co 228.616; Cr 283.563; Cu 324.754; \\
& Fe 259.940; Mg 279.553; Mn 257.610; Mo 202.030; Ni 221.647; Pb 220.353; \\
Analytes/ $\lambda(\mathrm{nm})$ & V 309.311; Zn 213.856. \\
\hline
\end{tabular}

An addition/recovery test for the elements under study was carried out in a meat sample by spiking ( 0.5 and $1.0 \mathrm{mg} / \mathrm{L}$ of each analyte). Table 4 shows that the method had a recovery interval of 
90-111\% for the spike of $0.5 \mathrm{mg} / \mathrm{L}$ and $93-112 \%$ for the spike of $1.0 \mathrm{mg} / \mathrm{L}$. Thus, the recovery test shows that there were no systematic errors or losses of elements during the digestion process.

Table 4. Addition recovery test on metals and metalloid.

\begin{tabular}{ccc}
\hline \multirow{2}{*}{ Analyte } & \multicolumn{2}{c}{ Spike Recovery (\%) } \\
\cline { 2 - 3 } & $\mathbf{0 . 5} \mathbf{~ m g / L}$ & $\mathbf{1 . 0} \mathbf{~} \mathbf{g} / \mathbf{L}$ \\
\hline $\mathrm{Al}$ & 108 & 108 \\
$\mathrm{As}$ & 102 & 103 \\
$\mathrm{Cd}$ & 91 & 93 \\
$\mathrm{Co}$ & 99 & 99 \\
$\mathrm{Cr}$ & 107 & 108 \\
$\mathrm{Cu}$ & 104 & 104 \\
$\mathrm{Fe}$ & 106 & 105 \\
$\mathrm{Mg}$ & 101 & 99 \\
$\mathrm{Mn}$ & 100 & 101 \\
$\mathrm{Mo}$ & 111 & 112 \\
$\mathrm{Ni}$ & 101 & 101 \\
$\mathrm{~Pb}$ & 90 & 93 \\
$\mathrm{~V}$ & 110 & 110 \\
$\mathrm{Zn}$ & 102 & 99 \\
\hline
\end{tabular}

\subsection{Calibration Procedure}

The calibration curves for all the analytes were built on nine different concentrations over the range of 0.005-2 mg/L. A multielement solution containing 100 mg/L Al, Cu, Fe, Mg, Mn, Mo, Ni, Co, V, and Zn (SpecSol-Quinlab, São Paulo, Brazil) and a monoelementar solution containing $100 \mathrm{mg} / \mathrm{L} \mathrm{As,} \mathrm{Cd,}$ $\mathrm{Cr}$, and $\mathrm{Pb}$ (SpecSol-Quinlab, São Paulo, Brazil) of each element were used to build calibration curves.

The calculation of the limits of detection (LOD) and limits of quantification (LOQ) was according to the analytical standards established by the IUPAC [31]. Table 5 shows the parameters of the calibration curve, as well as LOD and LOQ values and the obtained correlation coefficient $\left(R^{2}\right)$. The values of LOD were in the range 0.0002-0.0045 (mg/L) and the LOQ were 0.007-0.0151 (mg/L).

Table 5. Calibration equations $(y=a x+b) *$, correlation coefficients $\left(R^{2}\right)$, limits of detection (LOD), and limits of quantification (LOQ) obtained by external calibration.

\begin{tabular}{|c|c|c|c|c|}
\hline Element & $\begin{array}{c}\text { Equation External } \\
\text { Calibration } y=a x+b\end{array}$ & $\operatorname{LOD}(\mathrm{mg} / \mathrm{L})$ & LOQ (mg/L) & $R^{2}$ \\
\hline $\mathrm{Al}$ & $y=136.61 x-1.1213$ & 0.0045 & 0.0151 & 0.9994 \\
\hline As & $y=469.39 x+8.7286$ & 0.0029 & 0.0097 & 0.9995 \\
\hline $\mathrm{Cd}$ & $y=13845 x+102.27$ & 0.0002 & 0.0007 & 0.9998 \\
\hline $\mathrm{Co}$ & $y=5806.4 x+56.482$ & 0.0005 & 0.0016 & 0.9998 \\
\hline $\mathrm{Cr}$ & $y=18,084 x+87.356$ & 0.0011 & 0.0035 & 0.9998 \\
\hline $\mathrm{Cu}$ & $y=16,191 x+192.33$ & 0.0013 & 0.0042 & 0.9998 \\
\hline $\mathrm{Fe}$ & $y=10,923 x+122.77$ & 0.0011 & 0.0036 & 0.9998 \\
\hline $\mathrm{Mg}$ & $y=397,282 x+884.4$ & 0.0007 & 0.0024 & 0.9995 \\
\hline $\mathrm{Mn}$ & $y=57509 x+609.65$ & 0.0002 & 0.0005 & 0.9998 \\
\hline Mo & $y=3703.8 x+33.342$ & 0.0005 & 0.0015 & 0.9997 \\
\hline $\mathrm{Ni}$ & $y=5338.5 x+64.394$ & 0.0005 & 0.0016 & 0.9998 \\
\hline $\mathrm{Pb}$ & $y=1008.1 x+29.193$ & 0.0040 & 0.0132 & 0.9998 \\
\hline $\mathrm{V}$ & $y=34,980 x+359.82$ & 0.0004 & 0.0014 & 0.9998 \\
\hline $\mathrm{Zn}$ & $y=10,414 x+130.04$ & 0.0004 & 0.0014 & 0.9998 \\
\hline
\end{tabular}




\subsection{Human Health Risk Assessment}

The method used in this study was for non-carcinogenic and adapted from the method described by Onsanit et al. [9]. The human health risk was assessed by considering the EDI for a chemical contaminant in meats, as well as the intake amount of the meats. It is possible to calculate the EDI $(\mu \mathrm{g} / \mathrm{kg}$ bw/day) through consumption of food, using the following equation:

$$
E D I=C_{\text {meat }} x\left[\frac{d c_{\text {meat }}}{b w}\right]
$$

where, $C_{\text {meat }}, d c_{\text {meat }}$, and $b w$ (bodyweight) represent heavy metal content in raw and roasted meats $(\mu \mathrm{g} / \mathrm{g})$, daily meat consumption per capita (g/day), and the adult's body weight. The average weight of a Brazilian adult is $70 \mathrm{~kg}$, and the average daily consumption of beef, pork, poultry, and lamb in Brazil is $63.2,8.5,36.5$, and $0.8 \mathrm{~g} /$ person/day, respectively [32]. Other than that, the risk to human health by intake of heavy-metal-contaminated meats was characterized by using a hazard quotient $(H Q)$. The $H Q$ is a ratio of $E D I$ and chronic oral reference dose $(R f D)$, which is determined by the following equation:

$$
H Q=\frac{E D I}{R f D}
$$

The $R f D$ values for the risk calculation were established by the Joint Food and Agriculture Organization/World Health Organization Expert Committee on Food Additives [6] and the United States Environmental Protection Agency (USEPA) [33]. The RfD values for the elements are as follows: $\mathrm{Al}=0.4 \mu \mathrm{g} / \mathrm{kg} \mathrm{bw} /$ day, $\mathrm{As}=0.3 \mu \mathrm{g} / \mathrm{kg}$ bw/day, $\mathrm{Cr}=3 \mu \mathrm{g} / \mathrm{kg}$ bw $/$ day, $\mathrm{Cu}=$ not available, $\mathrm{Fe}=700 \mu \mathrm{g} / \mathrm{kg}$ bw/day, Mn = $140 \mu \mathrm{g} / \mathrm{kg}$ bw/day, Mo $=5 \mu \mathrm{g} / \mathrm{kg}$ bw/day, $\mathrm{V}=9 \mu \mathrm{g} / \mathrm{kg}$ bw/day, $\mathrm{Mg}=11,000 \mu \mathrm{g} / \mathrm{kg}$ bw/day, $\mathrm{Ni}=20 \mu \mathrm{g} / \mathrm{kg}$ bw/day, $\mathrm{Cd}=1 \mu \mathrm{g} / \mathrm{kg}$ bw/day, $\mathrm{Pb}=4 \mu \mathrm{g} / \mathrm{kg}$ bw/day, $\mathrm{Co}=30 \mu \mathrm{g} / \mathrm{kg} \mathrm{bw} /$ day, and $\mathrm{Zn}=300 \mu \mathrm{g} / \mathrm{kg}$ bw/day [33]. In Equation (2), toxic risk is considered to occur if $H Q>1$, while $H Q$ $<1$ represents negligible hazard (adverse non-carcinogenic effects).

\subsection{Statistical Analysis}

One-way ANOVA statistically analyzed differences between the groups, with post hoc Tukey's test multiple comparison in GraphPad Prism 8.0 software. The significance level was set at $p<0.05$.

\section{Results and Discussion}

In this section, the paper is organized as follows: Section 3.1 contains data on the concentration of major and trace elements obtained for raw and roasted meats, and the comparison of these values with studies carried out in other countries and published in the literature. In Section 3.2, we present the results obtained according to the type of elements quantified for each meat, since we consider that this is one of the factors that influences the calculation of the EDI, which is a common index for the transfer of metal from meat to man.

\subsection{The Concentration of Major and Trace Elements Obtained in Raw and Roasted Meats with Different Fuels}

Table 6 shows the major element $(\mathrm{Mg})$ and trace elements (Al, As, Cd, Cr, $\mathrm{Cu}, \mathrm{Fe}, \mathrm{Mn}, \mathrm{Mo}, \mathrm{Ni}, \mathrm{V}$, and $\mathrm{Zn}$ ) obtained by using ICP-OES in four different raw meat types, in an electric grill, and also from the respective meats roasted with six different types of wood and coal as burning fuels. Further details of the statistical results obtained from comparisons between samples are available in Supplementary Materials Figure S1. The metals $\mathrm{Co}$ and $\mathrm{Pb}$ were below the limit of detection. 
Table 6. Trace ( $\mathrm{Al}, \mathrm{As}, \mathrm{Cd}, \mathrm{Cr}, \mathrm{Cu}, \mathrm{Fe}, \mathrm{Mn}, \mathrm{Mo}, \mathrm{Ni}, \mathrm{V}$, and $\mathrm{Zn}$ ) and major ( $\mathrm{Mg}$ ) elements in different meat raw and roasted beef, pork, lamb, and chicken using different fuels.

\begin{tabular}{|c|c|c|c|c|c|c|c|c|}
\hline \multirow[b]{2}{*}{ Element } & \multicolumn{8}{|c|}{ Concentrations (Average Weight $\mathrm{mg} / \mathrm{kg} \pm \mathrm{SD}$ ) } \\
\hline & Raw Meat & $\begin{array}{l}\text { Electric Grill } \\
\text { Burgers }\end{array}$ & $\begin{array}{c}\text { Eucalyptus } \\
\text { citriodora Wood }\end{array}$ & $\begin{array}{c}\text { Guazuma } \\
\text { ulmifolia Wood }\end{array}$ & $\begin{array}{l}\text { Anadenanthera } \\
\text { falcata Wood }\end{array}$ & $\begin{array}{l}\text { CCA-Treated } \\
\text { Eucalyptus }\end{array}$ & $\begin{array}{c}\text { Eucalyptus } \\
\text { citriodora Coal }\end{array}$ & $\begin{array}{c}\text { Guazuma } \\
\text { ulmifolia Coal }\end{array}$ \\
\hline \multicolumn{9}{|l|}{$\mathrm{Al}$} \\
\hline Beef topside & $1.25 \pm 0.23^{\mathrm{a}}$ & $9.78 \pm 1.69^{\mathrm{d}}$ & $3.31 \pm 0.57^{\mathrm{a}, \mathrm{b}}$ & $6.53 \pm 1.52^{b, c}$ & $17.49 \pm 0.23^{\mathrm{f}}$ & $11.61 \pm 0.60^{\mathrm{e}}$ & $7.28 \pm 0.66^{c}$ & $27.79 \pm 0.71^{g}$ \\
\hline Pork loin & $0.86 \pm 0.12^{\mathrm{a}}$ & $25.53 \pm 0.21^{\mathrm{f}}$ & $2.85 \pm 0.50^{b}$ & $8.39 \pm 0.10^{c}$ & $15.33 \pm 0.46^{\mathrm{e}}$ & $11.59 \pm 0.59^{\mathrm{d}}$ & $9.11 \pm 0.67^{c}$ & $56.90 \pm 0.73 \mathrm{~g}$ \\
\hline Lamb shank & $1.54 \pm 0.55^{\mathrm{a}}$ & $16.32 \pm 0.25^{d}$ & $2.89 \pm 0.05^{\mathrm{a}}$ & $15.19 \pm 0.33^{c, d}$ & $12.12 \pm 0.64^{\mathrm{c}}$ & $17.18 \pm 1.92^{\mathrm{d}}$ & $6.56 \pm 0.13^{b}$ & $28.22 \pm 0.64^{\mathrm{e}}$ \\
\hline Chicken breast & $1.01 \pm 0.15^{\mathrm{a}}$ & $37.30 \pm 0.19^{\mathrm{e}}$ & $1.81 \pm 0.13^{\mathrm{a}}$ & $12.53 \pm 0.99^{c}$ & $23.12 \pm 0.86^{\mathrm{d}}$ & $12.91 \pm 0.32^{c}$ & $6.12 \pm 0.50^{b}$ & $46.46 \pm 1.03^{f}$ \\
\hline \multicolumn{9}{|l|}{ As } \\
\hline Beef topside & $0.23 \pm 0.10^{\mathrm{a}}$ & $0.55 \pm 0.12^{\mathrm{a}}$ & $0.55 \pm 0.45^{\mathrm{a}}$ & $0.29 \pm 0.03^{a}$ & $0.33 \pm 0.05^{a}$ & $21.04 \pm 0.14^{b}$ & $1.16 \pm 0.50^{\mathrm{a}}$ & $0.47 \pm 0.24^{\mathrm{a}}$ \\
\hline Pork loin & $0.17 \pm 0.42^{\mathrm{a}}$ & $0.55 \pm 0.04^{\mathrm{a}}$ & $0.30 \pm 0.23^{a}$ & $0.40 \pm 0.01^{\mathrm{a}}$ & $0.19 \pm 0.04^{\mathrm{a}}$ & $15.10 \pm 0.27^{b}$ & $0.83 \pm 0.60^{a}$ & $1.04 \pm 0.65^{\mathrm{a}}$ \\
\hline Lamb shank & ND & $0.67 \pm 0.07^{\mathrm{a}}$ & $0.64 \pm 0.18^{a}$ & $0.20 \pm 0.20^{a}$ & $0.10 \pm 0.02^{\mathrm{a}}$ & $17.61 \pm 0.50^{b}$ & $0.59 \pm 0.25^{\mathrm{a}}$ & $0.46 \pm 0.09^{a}$ \\
\hline Chicken breast & $0.19 \pm 0.36^{\mathrm{a}}$ & $0.57 \pm 0.02^{\mathrm{a}}$ & $0.55 \pm 0.53^{\mathrm{a}}$ & $0.37 \pm 0.06^{\mathrm{a}}$ & $0.37 \pm 0.01^{\mathrm{a}}$ & $26.25 \pm 1.47^{b}$ & $0.59 \pm 0.57^{\mathrm{a}}$ & $0.93 \pm 0.29^{a}$ \\
\hline \multicolumn{9}{|l|}{$\mathrm{Cd}$} \\
\hline Beef topside & ND & $0.09 \pm 0.03^{a}$ & ND & ND & ND & ND & ND & ND \\
\hline Pork loin & ND & $0.11 \pm 0.04^{\mathrm{a}}$ & ND & ND & ND & ND & ND & ND \\
\hline Lamb shank & ND & ND & ND & ND & ND & ND & ND & ND \\
\hline Chicken breast & ND & $0.12 \pm 0.01^{\mathrm{a}}$ & ND & ND & ND & ND & ND & ND \\
\hline \multicolumn{9}{|l|}{$\mathrm{Cr}$} \\
\hline Beef topside & $0.15 \pm 0.24^{\mathrm{a}}$ & $1.32 \pm 0.09^{b}$ & ND & ND & ND & $1.10 \pm 0.05^{b}$ & $0.004 \pm 0.001^{\mathrm{a}}$ & $0.66 \pm 0.55^{\mathrm{a}, \mathrm{b}}$ \\
\hline Pork loin & ND & $0.94 \pm 0.02^{b}$ & ND & $0.14 \pm 0.02^{\mathrm{a}}$ & $0.16 \pm 0.00^{\mathrm{a}}$ & $0.79 \pm 0.16^{b}$ & $0.08 \pm 0.012^{b}$ & $0.13 \pm 0.014^{\mathrm{a}}$ \\
\hline Lamb shank & ND & $0.25 \pm 0.06^{b}$ & ND & $0.09 \pm 0.00^{\mathrm{a}}$ & $0.03 \pm 0.04^{a}$ & $0.90 \pm 0.04^{c}$ & $0.03 \pm 0.05^{\mathrm{a}}$ & ND \\
\hline Chicken breast & ND & $0.55 \pm 0.01 \mathrm{a}, \mathrm{b}$ & ND & $0.10 \pm 0.02^{a}$ & $0.10 \pm 0.08^{a, b}$ & $0.89 \pm 0.37 b$ & ND & $0.14 \pm 0.11^{\mathrm{a}}$ \\
\hline \multicolumn{9}{|l|}{$\mathrm{Cu}$} \\
\hline Beef topside & $0.29 \pm 0.03^{a}$ & $0.94 \pm 0.00^{b}$ & $2.31 \pm 0.15^{\mathrm{d}}$ & $1.79 \pm 0.04^{c}$ & $1.66 \pm 0.02^{c}$ & $2.10 \pm 0.01^{\mathrm{c}, \mathrm{d}}$ & $1.28 \pm 0.14^{c}$ & $1.22 \pm 0.01^{b, c}$ \\
\hline Pork loin & ND & $0.53 \pm 0.01^{b}$ & $0.16 \pm 0.00^{a}$ & $0.17 \pm 0.02^{a}$ & $0.13 \pm 0.01^{a}$ & $0.71 \pm 0.16^{b}$ & $0.17 \pm 0.06^{a}$ & $0.33 \pm 0.12^{b}$ \\
\hline Lamb shank & $0.84 \pm 0.01^{\mathrm{a}}$ & $1.95 \pm 0.12^{c}$ & $1.04 \pm 0.09^{a, b}$ & $1.29 \pm 0.07^{b}$ & $0.83 \pm 0.02^{a}$ & $2.80 \pm 0.02^{\mathrm{d}}$ & $1.97 \pm 0.24^{c}$ & $2.10 \pm 0.09^{c}$ \\
\hline Chicken breast & ND & $0.23 \pm 0.01^{\mathrm{a}}$ & ND & $0.19 \pm 0.00^{\mathrm{a}}$ & $0.09 \pm 0.02^{\mathrm{a}}$ & $0.63 \pm 0.22^{b}$ & ND & $0.23 \pm 0.04^{\mathrm{a}}$ \\
\hline \multicolumn{9}{|l|}{$\mathrm{Fe}$} \\
\hline Beef topside & $37.52 \pm 1.58^{a}$ & & $37.87 \pm 2.01^{\mathrm{a}}$ & $33.73 \pm 0.05^{\mathrm{a}}$ & $36.54 \pm 0.47^{a}$ & $69.34 \pm 0.18^{b, c}$ & $82.03 \pm 16.08^{c}$ & $87.08 \pm 0.51^{\mathrm{c}}$ \\
\hline Pork loin & $5.18 \pm 0.26^{a}$ & $8.52 \pm 0.52^{\mathrm{a}}$ & $8.13 \pm 0.24^{a}$ & $11.68 \pm 0.81^{a}$ & $12.06 \pm 0.50^{a}$ & $9.18 \pm 0.40^{b}$ & $8.95 \pm 1.27^{b}$ & $11.58 \pm 1.19^{b}$ \\
\hline Lamb shank & $18.76 \pm 0.19^{a}$ & $26.97 \pm 3.22^{a, b}$ & $50.30 \pm 4.69^{c}$ & $71.71 \pm 5.36^{\mathrm{d}}$ & $58.84 \pm 0.48^{c}$ & $38.54 \pm 2.30^{b}$ & $34.43 \pm 2.24 \mathrm{~b}$ & $35.79 \pm 0.38^{b}$ \\
\hline Chicken breast & $4.58 \pm 0.76^{\mathrm{a}}$ & $5.33 \pm 0.12^{\mathrm{a}}$ & $7.82 \pm 0.11^{b}$ & $13.02 \pm 0.34^{\mathrm{c}, \mathrm{d}}$ & $15.65 \pm 0.54^{d}$ & $10.74 \pm 0.28^{b, c}$ & $6.92 \pm 0.34^{\mathrm{a}, \mathrm{b}}$ & $19.35 \pm 2.15^{\mathrm{e}}$ \\
\hline
\end{tabular}


Table 6. Cont.

\begin{tabular}{|c|c|c|c|c|c|c|c|c|}
\hline \multirow[b]{2}{*}{ Element } & \multicolumn{8}{|c|}{ Concentrations (Average Weight $\mathrm{mg} / \mathrm{kg} \pm \mathrm{SD}$ ) } \\
\hline & Raw Meat & $\begin{array}{l}\text { Electric Grill } \\
\text { Burgers }\end{array}$ & $\begin{array}{c}\text { Eucalyptus } \\
\text { citriodora Wood }\end{array}$ & $\begin{array}{c}\text { Guazuma } \\
\text { ulmifolia Wood }\end{array}$ & $\begin{array}{l}\text { Anadenanthera } \\
\text { falcata Wood }\end{array}$ & $\begin{array}{l}\text { CCA-Treated } \\
\text { Eucalyptus }\end{array}$ & $\begin{array}{c}\text { Eucalyptus } \\
\text { citriodora Coal }\end{array}$ & $\begin{array}{c}\text { Guazuma } \\
\text { ulmifolia Coal }\end{array}$ \\
\hline \multicolumn{9}{|l|}{$\mathrm{Mg}$} \\
\hline Beef topside & $218.47 \pm 3.95^{\mathrm{a}}$ & $267.62 \pm 2.95^{b}$ & $346.86 \pm 19.23^{c}$ & $307.96 \pm 2.89^{b, c}$ & $321.02 \pm 0.90^{c}$ & $346.76 \pm 7.66^{c}$ & $370.23 \pm 17.04^{c}$ & $355.36 \pm 13.18^{c}$ \\
\hline Pork loin & $225.55 \pm 8.08^{\mathrm{a}}$ & $293.32 \pm 1.58^{b}$ & $322.29 \pm 6.61^{b, c}$ & $354.44 \pm 3.91^{\mathrm{c}}$ & $335.53 \pm 1.90^{b, c}$ & $331.11 \pm 10.49^{b, c}$ & $366.53 \pm 24.81^{c}$ & $205.79 \pm 29.193^{\mathrm{a}}$ \\
\hline Lamb shank & $206.77 \pm 3.99^{a}$ & $252.79 \pm 4.58^{b}$ & $305.53 \pm 8.56^{c}$ & $359.58 \pm 13.99^{d}$ & $287.79 \pm 0.55^{b, c}$ & $342.67 \pm 11.25^{\mathrm{c}, \mathrm{d}}$ & $317.62 \pm 18.47^{\mathrm{c}, \mathrm{d}}$ & $332.96 \pm 13.80^{c, d}$ \\
\hline Chicken breast & $291.95 \pm 8.87^{\mathrm{a}}$ & $289.48 \pm 0.73^{a}$ & $345.90 \pm 1.12^{b}$ & $418.78 \pm 12.02^{c}$ & $407.88 \pm 3.07^{\mathrm{c}}$ & $414.27 \pm 1.44^{\mathrm{c}}$ & $333.30 \pm 2.32^{b}$ & $412.22 \pm 0.04^{\mathrm{c}}$ \\
\hline \multicolumn{9}{|l|}{ Mn } \\
\hline Beef topside & ND & $0.14 \pm 0.00^{\mathrm{a}, \mathrm{b}}$ & $0.96 \pm 0.07^{c}$ & $0.004 \pm 0.02^{a}$ & $0.25 \pm 0.02^{b}$ & $0.14 \pm 0.01^{\mathrm{a}, \mathrm{b}}$ & $0.86 \pm 0.08^{c}$ & $0.22 \pm 0.04^{b}$ \\
\hline Pork loin & ND & $0.10 \pm 0.00^{\mathrm{a}, \mathrm{b}}$ & $0.57 \pm 0.01^{b, c}$ & $0.02 \pm 0.03^{\mathrm{a}}$ & ND & ND & $1.00 \pm 0.36^{\mathrm{c}}$ & $0.11 \pm 0.02^{a, b}$ \\
\hline Lamb shank & ND & $0.13 \pm 0.01^{\mathrm{a}}$ & $0.55 \pm 0.06^{b}$ & $0.07 \pm 0.05^{\mathrm{a}}$ & $0.02 \pm 0.00^{\mathrm{a}}$ & $0.12 \pm 0.02^{\mathrm{a}}$ & $0.53 \pm 0.11^{b}$ & $0.18 \pm 0.04^{\mathrm{a}}$ \\
\hline Chicken breast & ND & $0.11 \pm 0.00^{\mathrm{a}}$ & $0.55 \pm 0.01 \mathrm{e}^{\mathrm{e}}$ & $0.12 \pm 0.04^{b}$ & $0.27 \pm 0.01^{\mathrm{c}}$ & $0.10 \pm 0.02^{b}$ & $0.27 \pm 0.01^{\mathrm{c}}$ & $0.45 \pm 0.03^{\mathrm{d}}$ \\
\hline \multicolumn{9}{|l|}{ Mo } \\
\hline Beef topside & ND & ND & $0.73 \pm 0.01^{\mathrm{c}}$ & $0.58 \pm 0.01^{b}$ & $0.55 \pm 0.00^{\mathrm{a}}$ & ND & ND & ND \\
\hline Pork loin & ND & ND & ND & ND & ND & ND & ND & ND \\
\hline Lamb shank & $0.45 \pm 0.05^{\mathrm{a}}$ & $1.00 \pm 0.04^{c}$ & ND & ND & ND & $0.67 \pm 0.04^{b}$ & $0.87 \pm 0.11^{b, c}$ & $0.92 \pm 0.07^{c}$ \\
\hline Chicken breast & ND & $0.01 \pm 0.00^{\mathrm{a}}$ & ND & ND & ND & ND & ND & ND \\
\hline \multicolumn{9}{|l|}{$\mathrm{Ni}$} \\
\hline Beef topside & ND & $0.49 \pm 0.02^{b}$ & ND & ND & ND & ND & ND & ND \\
\hline Pork loin & ND & $1.12 \pm 0.33^{b}$ & ND & ND & ND & ND & ND & ND \\
\hline Lamb shank & ND & $0.72 \pm 0.19^{b}$ & ND & ND & ND & ND & ND & ND \\
\hline Chicken breast & ND & $0.61 \pm 0.05^{b}$ & ND & ND & ND & ND & ND & ND \\
\hline \multicolumn{9}{|l|}{$\mathrm{V}$} \\
\hline Beef topside & $0.42 \pm 0.14^{\mathrm{a}}$ & $0.84 \pm 0.01^{b, c}$ & $0.97 \pm 0.03^{b, c}$ & $0.73 \pm 0.0^{b}$ & $0.80 \pm 0.02^{b, c}$ & $0.98 \pm 0.02^{b, c}$ & $1.02 \pm 0.06^{\mathrm{c}}$ & $1.08 \pm 0.09^{c}$ \\
\hline Pork loin & $0.39 \pm 0.02^{a}$ & $0.96 \pm 0.00^{b}$ & $0.81 \pm 0.02^{b}$ & $0.97 \pm 0.10^{b}$ & $0.83 \pm 0.03^{b}$ & $0.88 \pm 0.10^{b}$ & $1.04 \pm 0.13^{b, c}$ & $1.34 \pm 0.15^{c}$ \\
\hline Lamb shank & $0.55 \pm 0.36^{\mathrm{a}}$ & $0.78 \pm 0.02^{\mathrm{a}}$ & $0.70 \pm 0.07^{\mathrm{a}}$ & $0.97 \pm 0.09^{a}$ & $0.64 \pm 0.02^{\mathrm{a}}$ & $0.94 \pm 0.06^{\mathrm{a}}$ & $0.87 \pm 0.07^{a}$ & $0.92 \pm 0.03^{a}$ \\
\hline Chicken breast & $6.66 \pm 0.80^{a}$ & $9.30 \pm 0.02 b, c$ & $8.73 \pm 0.29^{a, b}$ & $13.82 \pm 1.06^{d}$ & $12.27 \pm 0.07^{\mathrm{c}, \mathrm{d}}$ & $11.33 \pm 0.20^{c}$ & $9.15 \pm 0.59^{b}$ & $16.29 \pm 0.40^{\mathrm{e}}$ \\
\hline \multicolumn{9}{|l|}{$\mathrm{Zn}$} \\
\hline Beef topside & $48.13 \pm 0.56^{\mathrm{a}}$ & $70.56 \pm 1.41^{b}$ & $46.73 \pm 2.39^{a}$ & $48.33 \pm 0.23^{a}$ & $47.98 \pm 0.57^{a}$ & $87.65 \pm 0.58^{c}$ & $92.25 \pm 10.29^{c}$ & $115.24 \pm 1.26^{\mathrm{d}}$ \\
\hline Pork loin & $10.97 \pm 0.26^{\mathrm{a}}$ & $18.07 \pm 0.27^{b}$ & $15.93 \pm 0.76^{b}$ & $17.61 \pm 1.24 b$ & $15.03 \pm 0.42^{b}$ & $15.67 \pm 0.50^{b}$ & $17.78 \pm 1.90^{b}$ & $21.16 \pm 1.22^{c}$ \\
\hline Lamb shank & $38.70 \pm 0.11^{\mathrm{a}}$ & $62.40 \pm 0.58^{c}$ & $65.56 \pm 2.82^{c, d}$ & $81.14 \pm 3.18^{\mathrm{e}}$ & $71.74 \pm 1.02^{d}$ & $47.62 \pm 1.99 \mathrm{~b}$ & $45.80 \pm 3.67^{\mathrm{a}, \mathrm{b}}$ & $76.97 \pm 1.53^{\mathrm{d}, \mathrm{e}}$ \\
\hline Chicken breast & $6.66 \pm 0.80^{\mathrm{a}}$ & $8.05 \pm 0.17^{\mathrm{a}, \mathrm{b}}$ & $8.73 \pm 0.29^{a, b}$ & $13.82 \pm 1.06^{\mathrm{c}}$ & $12.27 \pm 0.07^{c}$ & $11.33 \pm 0.20^{b, c}$ & $9.15 \pm 0.59^{b}$ & $16.29 \pm 0.40^{\mathrm{d}}$ \\
\hline
\end{tabular}

Notes: Different letters in the same line represent statistic differences amongst groups ( $p<0.05)$ by one-way ANOVA with post hoc Tukey's test. ND: not detectable; values ND assumed to be zero. CCA = Chromed Copper Arsenate. 


\subsubsection{Aluminum (Al)}

Table 6 shows the Al content in raw and roasted topside beef in the electric grill and with different burning fuels. There is no statistical difference between the content of $\mathrm{Al}$ in raw meats and in meats roasted with Eucalyptus citriodora wood; however, the values of this element in meats ranged from 1.25 to $3.31 \mathrm{mg} / \mathrm{kg}$. However, the concentration of $\mathrm{Al}$ is high in beef roasted with electric grill $(9.78 \pm 1.69 \mathrm{mg} / \mathrm{kg})$, as well as in CCA-treated Eucalyptus $(11.61 \pm 0.60 \mathrm{mg} / \mathrm{kg})$, Anadenanthera falcata wood $(17.49 \pm 0.23 \mathrm{mg} / \mathrm{kg})$, and Guazuma ulmifolia coal $(27.79 \pm 0.71 \mathrm{mg} / \mathrm{kg})$. In the pork samples, all treatments differed from the $\mathrm{Al}$ level in raw meat, but the values that most stood out were pork loin roasted with Anadenanthera falcata wood $(15.33 \pm 0.46 \mathrm{mg} / \mathrm{kg})$, electric grill $(25.53 \pm 0.21 \mathrm{mg} / \mathrm{kg})$, and Guazuma ulmifolia coal $(56.90 \pm 0.73 \mathrm{mg} / \mathrm{kg})$. The Al concentration in lamb shank portions roasted with Eucalyptus citriodora wood $(2.89 \pm 0.05 \mathrm{mg} / \mathrm{kg})$ did not diverge from the raw lamb sample $(1.54 \pm 0.55 \mathrm{mg} / \mathrm{kg})$. On the other hand, it exhibited intermediary levels after the treatment with Anadenanthera falcata wood, Guazuma ulmifolia wood, CCA-treated Eucalyptus and electric grill $(12.12 \pm 0.64-17.18 \pm 1.92 \mathrm{mg} / \mathrm{kg})$. In addition, higher levels of $\mathrm{Al}$ were found in lamb meat after roasting it with Guazuma ulmifolia coal $28.22 \pm 0.64 \mathrm{mg} / \mathrm{kg}$. The highest levels of $\mathrm{Al}$ in chicken breast meats appeared after roasting with Guazuma ulmifolia coal $(46.46 \pm 1.03 \mathrm{mg} / \mathrm{kg})$, followed by electric grill $(37.30 \pm 0.19 \mathrm{mg} / \mathrm{kg})$, and Anadenanthera falcata wood $(23.12 \pm 0.86 \mathrm{mg} / \mathrm{kg})$. All of these treatments differed from the raw chicken meat, except the chicken roasted with Eucalyptus citriodora wood. Thus, the Al concentrations in some groups are statistically different.

In Table 6, the content of $\mathrm{Al}$ in raw portions of meat as beef topside $(1.25 \pm 0.23 \mathrm{mg} / \mathrm{kg})$, pork loin $(0.86 \pm 0.12 \mathrm{mg} / \mathrm{kg})$, chicken breast $(1.01 \pm 0.15 \mathrm{mg} / \mathrm{kg})$, and lamb shank $(1.54 \pm 0.55 \mathrm{mg} / \mathrm{kg})$ is lower than those published in the literature in the Canary Islands by González-Weller et al. [34] for fresh cuts of chicken breast $(9.12 \pm 1.65 \mathrm{mg} / \mathrm{kg})$, pork $(9.78 \pm 5.14 \mathrm{mg} / \mathrm{kg})$, and beef $(8.74 \pm 4.72 \mathrm{mg} / \mathrm{kg})$, respectively. On the other hand, the Al concentration in our results and those quantified by González-Weller et al. [34] is higher than that found by Leblanc et al., for porcine muscle $(0.21 \mathrm{mg} / \mathrm{kg})$ and poultry $(0.26 \mathrm{mg} / \mathrm{kg})$ [35].

Notably, the roasting process with Guazuma ulmifolia coal affected all meat types, increasing the $\mathrm{Al}$ content in a significant manner, indicating that this kind of fuel may incorporate this metal to the meats through the smoking process.

\subsubsection{Arsenic (As)}

In Table 6, the As concentration raised significantly in all meat cuts roasted with CCA-treated Eucalyptus regarding the raw and grilled samples. Considering that the CCA-treated Eucalyptus receives a treatment of CCA, this high amount in this particular fuel is expected [24].

The content of As in raw samples of beef topside, pork loin, and chicken breast is superior than the results obtained in a research carried out in Saudi Arabia for red meat $0.01 \mathrm{mg} / \mathrm{kg}$ and raw chicken $0.03 \mathrm{mg} / \mathrm{kg}$ [36], and those found in studies in Italy for raw equine meat $0.068 \pm 0.005 \mathrm{mg} / \mathrm{kg}$ [37], and in Taiwan (raw beef $=0.008 \pm 0.009 \mathrm{mg} / \mathrm{kg}$ and pork $=0.018 \pm 0.027 \mathrm{mg} / \mathrm{kg}$ ) [38]. Nonetheless, our results are in the range level of As in meat reported by FAO/WHO $(0.004-0.78 \mathrm{mg} / \mathrm{kg})$ [2].

\subsubsection{Cadmium (Cd)}

$\mathrm{Cd}$ concentration was below the limit of detection in all raw and roasted samples of beef topside, pork loin, lamb shank, and chicken breast, using wood or charcoal as fuels (Table 6). With the exception of lamb shank, there was quantification of $\mathrm{Cd}$ in beef topside, pork loin, and chicken breast, using the electric grill, unlike in previous studies, where the $\mathrm{Cd}$ concentrations for raw and grilled meat remained the same or decreased (fresh > grilled) [15,39].

\subsubsection{Chromium (Cr)}

$\mathrm{Cr}$ was not detected in the raw samples of pork, lamb, and chicken, while the beef was the only fresh meat that contained this metal (Table 6). In all samples, the $\mathrm{Cr}$ concentration was higher in the 
meats roasted with CCA-treated Eucalyptus [40] and the electric grill, diverging from the raw meat in all meat types, but for chicken roasted with the electric grill. It is known that stainless steel equipment can contain Cr, to improve the corrosion resistance [41,42]. In fact, as we can see in Table 6, higher levels of $\mathrm{Cr}$ are quantified from using the electric grill and CCA wood. Thus, both CCA wood and the stainless steel barbecue may be the possible cause of contamination of $\mathrm{Cr}$ in the meat. Moreover, $\mathrm{Cr}$ content in raw beef topside was $0.15 \pm 0.24 \mathrm{mg} / \mathrm{kg}$, which is less than the values quantified in Saudi Arabia for raw red meat $(0.25 \mathrm{mg} / \mathrm{kg})$ [36], and Nigeria fresh bovine muscle $(1.24 \pm 0.52 \mathrm{mg} / \mathrm{kg})$ [43].

\subsubsection{Copper $(\mathrm{Cu})$}

In Table 6, the Cu content for all roasted beef varied around 0.29 to $2.31 \mathrm{mg} / \mathrm{k}$, showing a statistically significant difference in relation to the raw sample. The $\mathrm{Cu}$ content in pork samples registered significant differences when using Guazuma ulmifolia coal $(0.33 \pm 0.12 \mathrm{mg} / \mathrm{kg})$, electric grill $(0.53 \pm 0.01 \mathrm{mg} / \mathrm{kg})$, and CCA-treated Eucalyptus $(0.71 \pm 0.16 \mathrm{mg} / \mathrm{kg})$. The Cu content in raw lamb $(0.84 \pm 0.01 \mathrm{mg} / \mathrm{kg})$ differed from lamb roasted with the electric grill $(1.95 \pm 0.12 \mathrm{mg} / \mathrm{kg})$, Guazuma ulmifolia wood $(1.29 \pm 0.07 \mathrm{mg} / \mathrm{kg})$, Eucalyptus citriodora coal $(1.97 \pm 0.24 \mathrm{mg} / \mathrm{kg})$, and Guazuma ulmifolia coal $(2.10 \pm 0.09 \mathrm{mg} / \mathrm{kg})$. Moreover, higher levels of $\mathrm{Cu}$ occur in lambs roasted with CCA-treated Eucalyptus $(2.80 \pm 0.02 \mathrm{mg} / \mathrm{kg})$. As noted in other samples, the $\mathrm{Cu}$ levels in raw chicken show statistically significant differences in comparison with CCA-treated Eucalyptus samples $(0.63 \pm 0.22 \mathrm{mg} / \mathrm{kg})$. In fact, the presence of elements such as $\mathrm{Cu}$ in roasted meats can be explained due to the CCA-treated eucalyptus wood [24,40], composition of the fuel itself [20], and the contamination of the electric grill [41,42,44].

The values of $\mathrm{Cu}$ concentration in raw beef topside $(0.29 \pm 0.03 \mathrm{mg} / \mathrm{kg})$ (Table 6) are below the values found in raw beef in Zurich $(0.498 \pm 0.279 \mathrm{mg} / \mathrm{kg})$ [28] and Saudi Arabia (14.84 $\pm 0.40 \mathrm{mg} / \mathrm{kg})$ [45], as well as in muscle $(34.8 \pm 15.6 \mathrm{mg} / \mathrm{kg})$, liver $(22.3 \pm 11.1 \mathrm{mg} / \mathrm{kg})$, kidney $(20.4 \pm 5.9 \mathrm{mg} / \mathrm{kg})$, and heart $18.8 \pm 4.1 \mathrm{mg} / \mathrm{kg}$ of bovine collected from Egypt [29]. In Table 6, the concentration of $\mathrm{Cu}$ in raw lamb shank $(0.84 \pm 0.01 \mathrm{mg} / \mathrm{kg})$ was below than that found in the USA among lamb muscle groups with different origins, which varied from $1.30 \pm 0.04$ to $0.94 \pm 0.03 \mathrm{mg} / \mathrm{kg}$ [46].

\subsubsection{Iron $(\mathrm{Fe})$}

The Fe concentration changed considerably with kind of fuel used (Table 6). Highest Fe values obtained were in beef samples roasted with the Eucalyptus citriodora coal $(82.03 \pm 16.08 \mathrm{mg} / \mathrm{kg})$ and Guazuma ulmifolia coal $(87.08 \pm 0.51 \mathrm{mg} / \mathrm{kg})$. The levels of Fe in pork samples varied significantly for all fuels regarding the raw meat. However, roasting the pork in the electric grill $(8.52 \pm 0.52 \mathrm{mg} / \mathrm{kg})$, Eucalyptus citriodora $(8.13 \pm 0.24 \mathrm{mg} / \mathrm{kg})$, Anadenanthera falcata $(12.06 \pm 0.50 \mathrm{mg} / \mathrm{kg})$, and Guazuma ulmifolia $(11.68 \pm 0.81 \mathrm{mg} / \mathrm{kg})$ woods did produce a difference with the raw samples. Moreover, the Fe levels in lamb varied around $18.76-71.71 \mathrm{mg} / \mathrm{kg}$, with a significant difference for all roasted lamb samples, when compared to the raw, but for the one roasted in the electric grill. Likewise, Fe levels in chicken roasted with Anadenanthera falcata wood $(15.65 \pm 0.54 \mathrm{mg} / \mathrm{kg})$ were higher than that prepared with CCA-treated Eucalyptus (10.74 $\pm 0.28 \mathrm{mg} / \mathrm{kg})$, but lower when compared to the Guazuma ulmifolia coal $(19.35 \pm 2.15 \mathrm{mg} / \mathrm{kg})$. The increase in Fe content in all roasted meats may be partially related to the loss of water during the roasting process [47], or deposition of particles and gases from the wood or charcoal used [19-25].

Fe in raw beef topside $(37.52 \pm 1.58 \mathrm{mg} / \mathrm{kg})$ is higher than raw beef $(16 \pm 2$ to $25 \pm 8 \mathrm{mg} / \mathrm{kg})$ obtained in Zurich [28], and close to the value obtained by other Brazilian studies for beef ( $48 \pm 2 \mathrm{mg} / \mathrm{kg}$ ) [27]. On the other hand, the Fe content in pork loin $(5.18 \pm 0.26 \mathrm{mg} / \mathrm{kg})$, chicken breast $(4.58 \pm 0.76 \mathrm{mg} / \mathrm{kg})$, and lamb shank $(18.76 \pm 0.19 \mathrm{mg} / \mathrm{kg})$ is lower than the content obtained in pork loin $(7 \pm 6 \mathrm{mg} / \mathrm{kg})$, chicken breast without skin $(5 \pm 2 \mathrm{mg} / \mathrm{kg})$, and lamb chop $(20 \pm 7 \mathrm{mg} / \mathrm{kg})$ quantified in Zurich [28].

\subsubsection{Magnesium $(\mathrm{Mg})$}

Mg levels (Table 6) in beef augmented significantly after roasting with coals and woods; however, there were lower concentrations in the beef roasted in the electric grill $(267.62 \pm 2.95 \mathrm{mg} / \mathrm{kg})$ 
and Guazuma ulmifolia wood $(307.96 \pm 2.89 \mathrm{mg} / \mathrm{kg})$. In the present study, Mg levels in raw pork loin varied from the roasted samples, with a high concentration in Eucalyptus citriodora coal $(366.53 \pm 24.81 \mathrm{mg} / \mathrm{kg})$ and Guazuma ulmifolia wood $(354.44 \pm 3.91 \mathrm{mg} / \mathrm{kg})$. The Mg content in lamb samples was higher after roasting with different fuels, especially after the use of Guazuma ulmifolia wood $(359.58 \pm 13.99 \mathrm{mg} / \mathrm{kg}$ ). Likewise, Mg levels were high in chicken breast roasted with Guazuma ulmifolia wood (418.78 $\pm 12.02 \mathrm{mg} / \mathrm{kg})$, CCA-treated Eucalyptus $(414.27 \pm 1.44 \mathrm{mg} / \mathrm{kg})$, Guazuma ulmifolia coal $(412.22 \pm 0.04 \mathrm{mg} / \mathrm{kg})$, and Anadenanthera falcata wood $(407.88 \pm 3.07 \mathrm{mg} / \mathrm{kg})$.

Table 6 also shows that the concentration of $\mathrm{Mg}$ in raw beef topside, pork loin, chicken breast, and lamb shank were $218.47 \pm 3.95 \mathrm{mg} / \mathrm{kg}, 225.55 \pm 8.08 \mathrm{mg} / \mathrm{kg}, 291.95 \pm 86.87 \mathrm{mg} / \mathrm{kg}$, and $206.77 \pm 3.99 \mathrm{mg} / \mathrm{kg}$. Another Brazilian study carried out with bovine meat found that the $\mathrm{Mg}$ concentration was $700 \pm 28 \mathrm{mg} / \mathrm{kg}$ [27]. In Romania, according to results, the Mg level in pork loin was $40.511 \pm 1.62 \mathrm{mg} / \mathrm{kg}$ [26]. Studies carried out by the company Thermo Fisher Scientific, Cambridge, UK, using atomic flame absorption, obtained an amount of $19.579 \mathrm{mg} / \mathrm{kg}$ in chicken meat [48]. In Southern Italy, the mean values of $\mathrm{Mg}$ found in raw lamb meat samples ranged between $25.80 \pm 5.67$ and $37.24 \pm 2.27 \mathrm{mg} / \mathrm{kg}$ [49]. When comparing Mg levels presented in Table 6 with those obtained in other studies $[26,27,48,49]$, we found that metal concentrations in the meat cuts that we reported are far superior.

\subsubsection{Manganese (Mn)}

However, after the meats were roasted using different fuels, it was observed that the values of $\mathrm{Mn}$ concentrations were higher for roasted meats when we used Eucalyptus citriodora charcoal and firewood. In other words, the results demonstrate that wood and/or coal can accumulate Mn, causing the contamination of the meat through the emitted smoke. Except for the chicken breast, this pattern is correct for all other meat types. However, even the chicken breast did not show an elevated amount of Mn when roasted with Eucalyptus citriodora coal; the highest Mn concentration happens with Eucalyptus citriodora wood treatment. While we did not detect $\mathrm{Mn}$ in raw meats, results obtained in Zurich obtained Mn values in beef ranging from 31 to $108 \mathrm{mg} / \mathrm{kg}$, while, in pork meat, it varied from 62 to $128 \mathrm{mg} / \mathrm{kg}$; for chicken breast without skin, the concentration of Mn was $79 \mathrm{mg} / \mathrm{kg}$, and for lamb chop, the content of Mn was $167 \mathrm{mg} / \mathrm{kg}$ [28]. According to Gerber et al. [28], Mn concentrations vary unsystematically within muscles and species.

\subsubsection{Molybdenum (Mo)}

In Table 6, with the exception of raw lamb shank $(0.45 \pm 0.05 \mathrm{mg} / \mathrm{kg})$, the concentration of Mo in other raw meat is below the detection limit, as well as in samples roasted with most fuels. There was a statistical difference in Mo concentrations only in the sample of beef roasted with Anadenanthera falcata wood $(0.55 \pm 0.00 \mathrm{mg} / \mathrm{kg})$, Guazuma ulmifolia wood $(0.58 \pm 0.01 \mathrm{mg} / \mathrm{kg})$ and Eucalyptus citriodora wood $(0.73 \pm 0.01 \mathrm{mg} / \mathrm{kg})$. Molybdenum levels in all pork loin and chicken breast samples were below the analysis method detection limit, as the samples of roasted lamb with Eucalyptus citriodora wood, Guazuma ulmifolia wood, and Anadenanthera falcata wood. Therefore, the values of raw lamb and roasted lamb with CCA-treated Eucalyptus were superior to the latter but lower than the quantities of Mo in roasted lamb with the electric grill $(1.00 \pm 0.04 \mathrm{mg} / \mathrm{kg})$ and both types of coal.

\subsubsection{Nickel (Ni)}

The Ni concentration in the samples of raw meat and meat roasted with wood and charcoal are below the detection limit (Table 6). However, the detection of Ni occurred after cooking the meat types in the electric grill, suggesting contamination from the grill material. Higher concentrations of $\mathrm{Cr}$ and $\mathrm{Ni}$ have been recognized to improve the corrosion resistance of the grill. In addition, the literature data are conflicting due to differences between the materials used in each country [42]. According to a survey on the metal composition of kitchen grids, kitchen grids can be coated with enamel, to protect against corrosion and to facilitate cleaning. However, when heated, they can emit $\mathrm{As}, \mathrm{Pb}, \mathrm{Cd}, \mathrm{Cr}, \mathrm{Fe}$, 
$\mathrm{Co}, \mathrm{Li}$, and $\mathrm{Ni}$ [50]. Therefore, it is necessary to emphasize the importance of the quality of the product that may have influenced these results [41].

\subsubsection{Vanadium $(\mathrm{V})$}

The $\mathrm{V}$ concentrations in the raw meats and roasted are shown in Table 6. There were statistical differences in roasted beef, pork, and chicken samples. For beef, the $\mathrm{V}$ values increased mostly in the samples roasted with Eucalyptus citriodora coal (1.02 $\pm 0.06 \mathrm{mg} / \mathrm{kg})$ and Guazuma ulmifolia coal $(1.08 \pm 0.09 \mathrm{mg} / \mathrm{kg})$; the same happened in pork samples.

The samples of lambs raw or roasted with any type of fuel did not differ significantly between them. On the other hand, the highest levels of $\mathrm{V}$ in chicken were found in samples roasted with Guazuma ulmifolia wood $(13.82 \pm 1.06 \mathrm{mg} / \mathrm{kg})$ and charcoal $(16.29 \pm 0.40 \mathrm{mg} / \mathrm{kg})$.

According to studies carried out in Yugoslavia, the concentration of $\mathrm{V}$ in steaks, pork leg, and chicken breast was $0.4 \times 10^{-3} \mathrm{mg} / \mathrm{kg}, 0.6 \times 10^{-3} \mathrm{mg} / \mathrm{kg}$, and $1.7 \times 10^{-2} \mathrm{mg} / \mathrm{kg}$ [51]. In South Africa, the concentration of $\mathrm{V}$ in bovine muscle was $0.325 \pm 2 \times 10^{-3} \mathrm{mg} / \mathrm{kg}$ [52]. In Hong Kong, the concentration of $\mathrm{V}$ in beef, mutton, pork, and chicken meat was $1.5 \times 10^{-3} \mathrm{mg} / \mathrm{kg}$ for all samples [53]. In the USA, the concentrations of $\mathrm{V}$ in lamb muscles from different sources ranged from $0.25 \pm 0.18$ to $2.3 \pm 1.4 \mathrm{mg} / \mathrm{kg}$. Thus, it is observed that the values quantified in the meat of Table 6 are higher than those of the data found in Yugoslavia [51], South Africa [52], Hong Kong [53], and the USA [47].

\subsubsection{Zinc (Zn)}

In comparison with raw meats, it was observed that there was an increase in the concentration of $\mathrm{Zn}$ in all roasted meats, using different fuels (Table 6). In fact, variations in the concentration values of some elements such as $\mathrm{Fe}$ and $\mathrm{Zn}$ in meat samples can occur due to water loss during the cooking process [28]. However, the treatment with Guazuma ulmifolia coal elevated the Zn quantities the most, except for the lamb shank, which presented a higher $\mathrm{Zn}$ concentration when roasted with Guazuma ulmifolia wood. Again, these results imply that Guazuma ulmifolia may have an elevated amount of Zn in its composition and that it would be transferred to the food through the smoke.

The results obtained in our study are lower than those obtained in France for the concentration of $\mathrm{Zn}$ in pork $(36.76 \mathrm{mg} / \mathrm{kg}$ ) and chicken muscle $16.23 \mathrm{mg} / \mathrm{kg}$ [35], and cow muscle from Nigeria $(121.27 \pm 7.45 \mathrm{mg} / \mathrm{kg})$ [43]. In contrast, data concerning the concentration of $\mathrm{Zn}$ in seven chicken samples from different areas of Nigeria ranged from $6.12 \pm 0.15$ to $33.21 \pm 43.34 \mathrm{mg} / \mathrm{kg}$ [54]. Meanwhile, $\mathrm{Zn}$ concentrations in Morocco for cattle and sheep meats were $9.04 \pm 0.17$ and $6.97 \pm 0.17 \mathrm{mg} / \mathrm{kg}$, respectively. Thus, the zinc concentration values in Table 6 are close to the minimum values obtained in Nigeria for chicken samples. Moreover, the concentration of $\mathrm{Zn}$ in raw beef topside and raw lamb shank is higher than in Morocco for cattle meat had and sheep meat [54,55].

\subsubsection{Metal and Metalloid Content Regarding Meat Types and Relationship with the Fuel}

The result of the present study showed that meat roasted with charcoal has a lower level of trace elements when compared to meat roasted with firewood. $\mathrm{Mg}$ has reported the highest level, while $\mathrm{Al}$, $\mathrm{Fe}, \mathrm{Cr}, \mathrm{Cd}, \mathrm{Ni}$, and $\mathrm{As}$ were the lowest in all meat types. Moreover, all roasted meat with wood fire from CCA-treated Eucalyptus presented high levels of $\mathrm{As}, \mathrm{Cu}$, and $\mathrm{Cr}$, which can relate to the presence of these elements in the wood treated with CCA [22-25]. Although this kind of wood is often used as a burning fuel to barbecue, the presence of toxic metals and metalloids, such As, and subsequent release and impregnation of this contaminant in food through smoke make its use unsafe. In the meat types roasted with coal, the level of $\mathrm{As}, \mathrm{Cu}$, and $\mathrm{Cr}$ were lower than in roasted meat with wood treated with CCA (Table 6).

The combustion of coal releases particles that contaminate the meat with amounts that cannot be neglected [20]; for some elements, such as $\mathrm{Al}$, the sum of the elemental deposition from fuel increased the initial concentration in over 37-fold. Furthermore, previous research investigating a total of 24 quantified elements ( $\mathrm{Al}, \mathrm{Ag}$, As, Be, Bi, $\mathrm{Ca}, \mathrm{Ca}, \mathrm{Ce}, \mathrm{Co}, \mathrm{Cr}, \mathrm{Cs}, \mathrm{Cu}, \mathrm{Fe}, \mathrm{La}, \mathrm{Mg}, \mathrm{Mn}, \mathrm{Mo}, \mathrm{Ni}, \mathrm{Pb}$, 
$\mathrm{Rb}, \mathrm{Se}, \mathrm{Sr}, \mathrm{V}$, and $\mathrm{Zn}$ ) associated the inhaling of the elemental fine airborne particles released during charcoal combustion with health hazards. Moreover, changes in fatty acids concentration during the grilling of meat, as told by Rogge et al. [56], led to the higher production of aerosols made of fatty acids from oil or grease droplets that fall into the heat source, where they would vaporize and renucleate and grow into small particles; considering the distance between the meat and the heat source, in the case of electric grills and other types of portable grills, it would be an aggravating factor. The elements As, $\mathrm{Cr}$, Se, V, and $\mathrm{Zn}$ were the most abundant metals identified in the fine particles [21]. Studies on daily exposure of a grill operator, while grilling meat [19], and the potential risk associated with the use of BBQ charcoal $[20,21]$, indicate that the lifetime risk of cancer associated with exposure to As and $\mathrm{Cr}$ is significant in restaurants [21], and in domestic use, which becomes a public health problem.

In the case of enameled steel and cast-iron grills used in grills, the Federal Institute for Risk Assessment $(B f R)$ examined whether and to what extent the metallic elements of the enamel layer of the grates are released during cooking and can therefore pass for grilled foods. It was found that, in some materials of the examined grids, considerable amounts of aluminum, antimony, arsenic, and nickel escape. The BfR assessed the integrity of the results and concluded that the health-tolerable exposure values are sometimes significantly exceeded [50].

\subsection{Estimated Daily Intake (EDI) through Meats Consumption}

$E D I$ and $H Q$ for individual elements caused by the intake of different roasted-meat types with different fuels are estimated in Tables 7 and 8 . The EDI and HQ of elements through roasted beef topside and roasted pork loin consumption in Brazil are presented in Table 7, and for the elements due to the consumption of roasted chicken breast and roasted lamb shank are in Table 8. The EDI of all studied major and trace elements was calculated based on mean meats consumption in Brazil (g/person/day).

\subsubsection{Aluminum (Al)}

The EDI of Al due to intake for roasted beef topside with electric grill, wood fire, and coals ranged from 2.9885 to $25.2078 \mu \mathrm{g} / \mathrm{kg}$ bw/day. For roasted pork loin with electric grill, wood fire and coals, the EDI of Al due to intake of this meat ranged from 0.3461 to $6.9093 \mu \mathrm{g} / \mathrm{kg}$ bw/day (Table 7). The EDI of $\mathrm{Al}$ through roast chicken breast meat consumption ranged from 0.9438 to $24.2256 \mu \mathrm{g} / \mathrm{kg} \mathrm{bw} / \mathrm{day}$, and roasted lamb shank ranged from 0.0330 to $0.3225 \mu \mathrm{g} / \mathrm{kg} \mathrm{bw} /$ day (Table 8). The provisional tolerable daily intake (PTDI) suggested by the JECFA for $\mathrm{Al}$ is $285 \mu \mathrm{g} / \mathrm{kg}$ bw/day [57]. On the other hand, the MRL of $1000 \mu \mathrm{g} \mathrm{Al} / \mathrm{kg} /$ day has been derived for intermediate-duration oral exposure (15-364 days) to $\mathrm{Al}$ [13]. Therefore, EDI values of $\mathrm{Al}$ are below the exposure limit of the JECFA and values of the MRL, when considering the consumption of roasted meats only.

In Table 7, except for the roasted pork loin with wood fire from Eucalyptus citriodora, beef topside, and pork loin, both roasted with other wood and coal presented $H Q$ values of $\mathrm{Al}$ for adults superior to 1. Besides, in Table 8, samples of roasted chicken breast with wood fire and coal had $H Q$ values for $\mathrm{Al}$ above 1 for adults. That is, the results show that, in the exposed population, chronic health risks may occur. On the other hand, roasted lamb shank with wood fire and coal showed $H Q$ values of $\mathrm{Al}$ for adults below 1 , indicating that the consumption of this roasted meat may not cause adverse effects to the health of the population that consumes it. It is critical to highlight that those values are considering only meat consumption and not the smoke exposure or other contaminations sources, which would add to that, worsening the problem. According to studies, people exposed to high levels of Al may develop neurological impairments, such as Alzheimer's disease [58,59]. 
Table 7. Estimated daily intakes (EDI, $\mu \mathrm{g} / \mathrm{kg}$ bw/day) and hazard quotient $(H Q)$ of elements through roasted beef topside and roasted pork loin consumption in Brazil.

\begin{tabular}{|c|c|c|c|c|c|c|c|c|c|c|c|c|c|}
\hline Sample & & Al & As & $\mathrm{Cd}$ & $\mathrm{Cr}$ & $\mathrm{Cu}$ & $\mathrm{Fe}$ & Mg & Mn & Mo & $\mathrm{Ni}$ & $\mathbf{V}$ & $\mathrm{Zn}$ \\
\hline \multirow{2}{*}{ roasted beef topside with electric grill } & $E D I$ & 8.8299 & 0.4966 & 0.0813 & 1.1918 & 0.8487 & 43.8698 & 241.6226 & 0.1264 & - & 0.4424 & 0.7584 & 63.7056 \\
\hline & $H Q$ & 22.0749 & 1.6552 & 0.0813 & 0.3973 & - & 0.0627 & 0.2197 & 0.0009 & - & 0.0221 & 0.0843 & 0.2124 \\
\hline \multirow{2}{*}{$\begin{array}{l}\text { roasted beef topside with wood fire } \\
\text { from Eucalyptus citriodora }\end{array}$} & $E D I$ & 2.9885 & 0.4966 & - & - & 2.0856 & 34.1912 & 313.1650 & 0.8667 & 0.6591 & - & 0.8758 & 42.1905 \\
\hline & $H Q$ & 7.4711 & 1.6552 & - & - & - & 0.0488 & 0.0285 & 0.0062 & 0.1318 & - & 0.0973 & 0.1406 \\
\hline \multirow{2}{*}{$\begin{array}{l}\text { roasted beef topside with wood fire } \\
\text { from Guazuma ulmifolia }\end{array}$} & $E D I$ & 5.8957 & 0.2618 & - & - & 1.6161 & 30.4534 & 278.0439 & 0.0036 & 0.5237 & - & 0.6591 & 43.6351 \\
\hline & $H Q$ & 14.7391 & 0.8728 & - & - & - & 0.0435 & 0.0253 & 0.00003 & 0.1047 & - & 0.0732 & 0.1455 \\
\hline \multirow{2}{*}{$\begin{array}{l}\text { roasted beef topside with wood fire } \\
\text { from Anadenanthera falcate }\end{array}$} & $E D I$ & 15.7910 & 0.2979 & - & - & 1.4987 & 32.9904 & 289.8352 & 0.2257 & 0.4966 & - & 0.7223 & 43.3191 \\
\hline & $H Q$ & 39.4774 & 0.9931 & - & - & - & 0.0471 & 0.0263 & 0.0016 & 0.0993 & - & 0.0803 & 0.1444 \\
\hline \multirow{2}{*}{$\begin{array}{l}\text { roasted beef topside with wood fire } \\
\text { from CCA-treated Eucalyptus }\end{array}$} & $E D I$ & 10.4822 & 18.9961 & - & 0.9931 & 1.8960 & 62.6041 & 313.0747 & 0.1264 & - & - & 0.8848 & 79.1354 \\
\hline & $H Q$ & 26.2054 & 63.3204 & - & 0.3310 & - & 0.0894 & 0.0285 & 0.0009 & - & - & 0.0983 & 0.2638 \\
\hline \multirow{2}{*}{$\begin{array}{l}\text { roasted beef topside with coal fire } \\
\text { from Eucalyptus citriodora }\end{array}$} & $E D I$ & 6.5728 & 1.0473 & - & 0.0036 & 1.1557 & 74.0614 & 334.2648 & 0.7765 & - & - & 0.9209 & 83.2886 \\
\hline & $H Q$ & 16.4320 & 3.4910 & - & 0.0012 & - & 0.1058 & 0.0304 & 0.0055 & - & - & 0.1023 & 0.2776 \\
\hline \multirow{2}{*}{$\begin{array}{l}\text { roasted beef topside with coal fire } \\
\text { from Guazuma ulmifolia }\end{array}$} & $E D I$ & 25.2078 & 0.4243 & - & 0.5959 & 1.1015 & 78.6208 & 320.8393 & 0.1986 & - & - & 0.9751 & 104.0453 \\
\hline & $H Q$ & 63.0194 & 1.4145 & - & 0.1986 & - & 0.1123 & 0.0292 & 0.0014 & - & - & 0.1083 & 0.3468 \\
\hline \multirow{2}{*}{ roasted pork loin with electric grill } & $E D I$ & 3.1001 & 0.0668 & 0.0134 & 0.1141 & 0.0644 & 1.0346 & 35.6174 & 0.0121 & - & 0.1360 & 0.1166 & 2.1942 \\
\hline & $H Q$ & 7.7502 & 0.2226 & 0.0134 & 0.0380 & - & 0.0015 & 0.0324 & 0.0001 & - & 0.0068 & 0.0130 & 0.0073 \\
\hline \multirow{2}{*}{$\begin{array}{l}\text { roasted pork loin with wood fire } \\
\text { from Eucalyptus citriodora }\end{array}$} & EDI & 0.3461 & 0.0364 & - & - & 0.0194 & 0.9872 & 39.1352 & 0.0692 & - & - & 0.0984 & 1.9344 \\
\hline & $H Q$ & 0.8652 & 0.1214 & - & - & - & 0.0014 & 0.0036 & 0.0005 & - & - & 0.0109 & 0.0064 \\
\hline \multirow{2}{*}{$\begin{array}{l}\text { roasted pork loin with wood fire } \\
\text { from Guazuma ulmifolia }\end{array}$} & $E D I$ & 1.0188 & 0.0486 & - & 0.0170 & 0.0206 & 1.4183 & 43.0391 & 0.0024 & - & - & 0.1178 & 2.1384 \\
\hline & $H Q$ & 2.5470 & 0.1619 & - & 0.0057 & - & 0.0020 & 0.0039 & 0.00002 & - & - & 0.0131 & 0.0071 \\
\hline \multirow{2}{*}{$\begin{array}{l}\text { roasted pork loin with wood fire } \\
\text { from Anadenanthera falcate }\end{array}$} & $E D I$ & 1.8615 & 0.0231 & - & 0.0194 & 0.0158 & 1.4644 & 40.7429 & - & - & - & 0.1008 & 1.8251 \\
\hline & $H Q$ & 4.6538 & 0.0769 & - & 0.0065 & - & 0.0021 & 0.0037 & - & - & - & 0.0112 & 0.0061 \\
\hline \multirow{2}{*}{$\begin{array}{l}\text { roasted pork loin with wood fire } \\
\text { from CCA-treated Eucalyptus }\end{array}$} & $E D I$ & 1.4074 & 1.8336 & - & 0.0959 & 0.0862 & 1.1147 & 40.2062 & - & - & - & 0.1069 & 1.9028 \\
\hline & $H Q$ & 3.5184 & 6.1119 & - & 0.0320 & - & 0.0016 & 0.0037 & - & - & - & 0.0119 & 0.0063 \\
\hline \multirow{2}{*}{$\begin{array}{l}\text { roasted pork loin with coal fire from } \\
\text { Eucalyptus citriodora }\end{array}$} & $E D I$ & 1.1062 & 0.1008 & - & 0.0097 & 0.0206 & 1.0868 & 44.5072 & 0.1214 & - & - & 0.1263 & 2.1590 \\
\hline & $H Q$ & 2.7655 & 0.3360 & - & 0.0032 & - & 0.0016 & 0.0040 & 0.0009 & - & - & 0.0140 & 0.0072 \\
\hline \multirow{2}{*}{$\begin{array}{l}\text { roasted pork loin with coal fire from } \\
\text { Guazuma ulmifolia }\end{array}$} & $E D I$ & 6.9093 & 0.1263 & - & 0.0158 & 0.0401 & 1.4061 & 24.9888 & 0.0134 & - & - & 0.1627 & 2.5694 \\
\hline & $H Q$ & 17.2732 & 0.4210 & - & 0.0053 & - & 0.0020 & 0.0023 & 0.0001 & - & - & 0.0181 & 0.0086 \\
\hline
\end{tabular}


Table 8. Estimated daily intakes (EDI, $\mu \mathrm{g} / \mathrm{kg}$ bw/day) and hazard quotient $(H Q)$ of elements through roasted chicken breast and roasted lamb shank in Brazil.

\begin{tabular}{|c|c|c|c|c|c|c|c|c|c|c|c|c|c|}
\hline Sample & & Al & As & $\mathrm{Cd}$ & $\mathrm{Cr}$ & $\mathrm{Cu}$ & $\mathrm{Fe}$ & $\mathrm{Mg}$ & Mn & Mo & $\mathrm{Ni}$ & $\mathrm{V}$ & $\mathrm{Zn}$ \\
\hline \multirow{2}{*}{$\begin{array}{l}\text { roasted chicken breast with electric } \\
\text { grill }\end{array}$} & $E D I$ & 19.4493 & 0.2972 & 0.0626 & 0.2868 & 0.1199 & 2.7792 & 150.9431 & 0.0574 & 0.0052 & 0.3181 & 4.8493 & 4.1975 \\
\hline & $H Q$ & 48.6232 & 0.9907 & 0.0626 & 0.0956 & - & 0.0040 & 0.1372 & 0.0004 & 0.0010 & 0.0159 & 0.5388 & 0.0140 \\
\hline \multirow{2}{*}{$\begin{array}{l}\text { roasted chicken breast with wood fire } \\
\text { from Eucalyptus citriodora }\end{array}$} & $E D I$ & 0.9438 & 0.2868 & - & - & - & 4.0776 & 180.3621 & 0.2868 & - & - & 0.4745 & 4.5521 \\
\hline & $H Q$ & 2.3595 & 0.9560 & - & - & - & 0.0058 & 0.0164 & 0.0020 & - & - & 0.0527 & 0.0152 \\
\hline \multirow{2}{*}{$\begin{array}{l}\text { roasted chicken breast with wood fire } \\
\text { from Guazuma ulmifolia }\end{array}$} & $E D I$ & 6.5335 & 0.1929 & - & 0.0521 & 0.0991 & 6.7890 & 218.3639 & 0.0626 & - & - & 0.7821 & 7.2061 \\
\hline & $H Q$ & 16.3338 & 0.6431 & - & 0.0174 & - & 0.0097 & 0.0199 & 0.0004 & - & - & 0.0869 & 0.0240 \\
\hline \multirow{2}{*}{$\begin{array}{l}\text { roasted chicken breast with wood fire } \\
\text { from Anadenanthera falcate }\end{array}$} & $E D I$ & 12.0554 & 0.1929 & - & 0.0521 & 0.0469 & 8.1604 & 212.6803 & 0.1408 & - & - & 0.6883 & 6.3979 \\
\hline & $H Q$ & 30.1386 & 0.6431 & - & 0.0174 & - & 0.0117 & 0.0193 & 0.0010 & - & - & 0.0765 & 0.0213 \\
\hline \multirow{2}{*}{$\begin{array}{l}\text { roasted chicken breast with wood fire } \\
\text { from CCA-treated Eucalyptus }\end{array}$} & $E D I$ & 6.7316 & 13.6875 & - & 0.4641 & 0.3285 & 5.6001 & 216.0122 & 0.0521 & - & - & 0.7196 & 5.9078 \\
\hline & $H Q$ & 16.8291 & 45.6250 & - & 0.1547 & - & 0.0080 & 0.0196 & 0.0004 & - & - & 0.0800 & 0.0197 \\
\hline \multirow{2}{*}{$\begin{array}{l}\text { roasted chicken breast with coal fire } \\
\text { from Eucalyptus citriodora }\end{array}$} & $E D I$ & 3.1911 & 0.3076 & - & - & - & 3.6083 & 173.7921 & 0.1408 & - & - & 0.4536 & 4.7711 \\
\hline & $H Q$ & 7.9779 & 1.0255 & - & - & - & 0.0052 & 0.0158 & 0.0010 & - & - & 0.0504 & 0.0159 \\
\hline \multirow{2}{*}{$\begin{array}{l}\text { roasted chicken breast with coal fire } \\
\text { from Guazuma ulmifolia }\end{array}$} & $E D I$ & 24.2256 & 0.4849 & - & 0.0730 & 0.1199 & 10.0896 & 214.9433 & 0.2346 & - & - & 0.9021 & 8.4941 \\
\hline & $H Q$ & 60.5639 & 1.6164 & - & 0.0243 & - & 0.0144 & 0.0195 & 0.0017 & - & - & 0.1002 & 0.0283 \\
\hline \multirow{2}{*}{ roasted lamb shank with electric grill } & $E D I$ & 0.1865 & 0.0077 & - & 0.1768 & 0.0029 & 0.0223 & 0.3082 & 2.8890 & 0.0015 & 0.0114 & 0.0089 & 0.7131 \\
\hline & $H Q$ & 0.4663 & 0.0255 & - & 0.4420 & - & - & 0.0004 & 0.0026 & 0.0000 & 0.0023 & 0.0010 & 0.0024 \\
\hline \multirow{2}{*}{$\begin{array}{l}\text { roasted lamb shank with wood fire } \\
\text { from Eucalyptus citriodora }\end{array}$} & $E D I$ & 0.0330 & 0.0073 & - & - & 0.0119 & 0.5749 & 3.4918 & 0.0063 & - & - & 0.0080 & 0.7493 \\
\hline & $H Q$ & 0.0826 & 0.0244 & - & - & - & 0.0008 & 0.0003 & 0.00004 & - & - & 0.0009 & 0.0025 \\
\hline \multirow{2}{*}{$\begin{array}{l}\text { roasted lamb shank with wood fire } \\
\text { from Guazuma ulmifolia }\end{array}$} & $E D I$ & 0.1736 & 0.0023 & - & 0.0010 & 0.0147 & 0.8195 & 4.1095 & 0.0008 & - & - & 0.0111 & 0.9273 \\
\hline & $H Q$ & 0.4340 & 0.0076 & - & 0.0003 & - & 0.0012 & 0.0004 & 0.00001 & - & - & 0.0012 & 0.0031 \\
\hline \multirow{2}{*}{$\begin{array}{l}\text { roasted lamb shank with wood fire } \\
\text { from Anadenanthera falcate }\end{array}$} & $E D I$ & 0.1385 & 0.0011 & - & 0.0003 & 0.0095 & 0.6725 & 3.2890 & 0.0002 & - & - & 0.0073 & 0.8199 \\
\hline & $H Q$ & 0.3462 & 0.0038 & - & 0.0001 & - & 0.0010 & 0.0003 & 0.000002 & - & - & 0.0008 & 0.0027 \\
\hline \multirow{2}{*}{$\begin{array}{l}\text { roasted lamb shank with wood fire } \\
\text { from CCA-treated Eucalyptus }\end{array}$} & $E D I$ & 0.1963 & 0.2013 & - & 0.0103 & 0.0320 & 0.4405 & 3.9162 & 0.0014 & 0.0077 & - & 0.0107 & 0.5442 \\
\hline & $H Q$ & 0.4909 & 0.6709 & - & 0.0034 & - & 0.0006 & 0.0004 & 0.00001 & 0.0015 & - & 0.0012 & 0.0018 \\
\hline \multirow{2}{*}{$\begin{array}{l}\text { roasted lamb shank coal fire from } \\
\text { Eucalyptus citriodora }\end{array}$} & $E D I$ & 0.0750 & 0.0067 & - & 0.0003 & 0.0225 & 0.3935 & 3.6299 & 0.0061 & 0.0099 & - & 0.0099 & 0.5234 \\
\hline & $H Q$ & 0.1874 & 0.0225 & - & 0.0001 & - & 0.0006 & 0.0003 & 0.00004 & 0.0020 & - & 0.0011 & 0.0017 \\
\hline \multirow{2}{*}{$\begin{array}{l}\text { roasted lamb shank coal fire from } \\
\text { Guazuma ulmifolia }\end{array}$} & $E D I$ & 0.3225 & 0.0053 & - & - & 0.0240 & 0.4090 & 3.8053 & 0.0021 & 0.010 & - & 0.0105 & 0.8797 \\
\hline & $H Q$ & 0.8063 & 0.0175 & - & - & - & 0.0006 & 0.0003 & 0.00001 & 0.0021 & - & 0.0012 & 0.0029 \\
\hline
\end{tabular}




\subsubsection{Arsenic (As)}

$E D I$ of As values due to consumption of roasted beef meat with electric grill, wood, and coals varied from 0.2618 to $18.9961 \mu \mathrm{g} / \mathrm{kg}$ bw/day, while the roasted pork loin with electric grill, wood fire, and coal ranged from 0.0231 to $1.8336 \mu \mathrm{g} / \mathrm{kg}$ bw/day (Table 7). Moreover, the EDI of As due to intake of roasted chicken breast meat consumption ranged from 0.1929 to $13.6875 \mu \mathrm{g} / \mathrm{kg}$ bw/day, and roast lamb shank EDI values were between 0.0011 and $0.2013 \mu \mathrm{g} / \mathrm{kg}$ bw/day (Table 8).

Since the PTWI established by JEFCA for As was considered no longer appropriate, the risk assessment was performed by using the $\mathrm{BMDL}_{01}$ that the EFSA has established to estimate the dietary risk, ranging values between 0.3 and $8 \mu \mathrm{g} / \mathrm{kg}$ bw/day for cancers of the lung, bladder, and skin $[7,60]$. On the other hand, the ATSDR has established an MRL for As of $0.3 \mu \mathrm{g} / \mathrm{kg}$ bw/day for chronic duration exposure ( $\geq 1$ year) [13]. EDI values for As in some roasted meats, compared with those proposed by both EFSA and JECFA, demonstrated that EDI values are above this limit.

Table 7 shows that the concentration of As for the roasted beef meat with wood fire from Guazuma ulmifolia and Anadenanthera falcata, where the values of $H Q$ are inferior to 1 . However, the other samples of roast beef meat with electric grill, wood fire, and coal presented values above 1 . Only the roasted pork loin with wood fire from CCA-treated Eucalyptus had values $H Q$ of As for adults greater than 1 . In the same way, $H Q$ of As for adults is greater than 1 for roasted chicken breast with coal fire from Eucalyptus citriodora, roasted chicken breast with coal fire from Guazuma ulmifolia, and roasted chicken breast with wood fire from CCA-treated Eucalyptus. All other samples have $H Q$ reference values lower than 1 , meaning that no adverse effects are expected, while $H Q$ above 1 can be a concern regarding adverse non-carcinogenic effects.

As is toxic in its inorganic and organic forms. Long-term exposure to As, mainly through cereal grains and food [61], can lead to chronic As poisoning [62]. Thus, the possibility of risk to some consumers is patent.

\subsubsection{Cadmium $(\mathrm{Cd})$}

The Cd EDI concentration in Tables 7 and 8 was below the limit of detection in all raw and roasted samples of beef, pork, lamb, and chicken, except for the meat cuts cooked on the electric grill. However, the $H Q$ values of $\mathrm{Cd}$ for adults in electric-grill-roasted meats were still less than 1 . Moreover, the values of the MRL derived for intermediate-duration (15-364 days) and chronic (1 year or longer) oral exposure for $\mathrm{Cd}$ is $0.5 \mu \mathrm{g} / \mathrm{kg}$ bw/day and $0.1 \mu \mathrm{g} / \mathrm{kg}$ bw/day, respectively [13]. Thus, the results obtained for $\mathrm{Cd}$ in electric grill are within this limit.

\subsubsection{Chromium (Cr)}

The EDI of Cr due to intake of roasted beef and pork with wood fire and coals ranged from 0.0036 to $0.9931 \mu \mathrm{g} / \mathrm{kg}$ bw/day and 0.0097 to $0.0959 \mu \mathrm{g} / \mathrm{kg}$ bw/day, respectively (Table 7). Meanwhile, the EDI for $\mathrm{Cr}$ in roasted chicken breast ranged from 0.0521 to $0.4641 \mu \mathrm{g} / \mathrm{kg}$ bw/day, and for lamb shank from 0.0003 to $0.0103 \mu \mathrm{g} / \mathrm{kg} \mathrm{bw} /$ day, correspondingly. There is no suggested value of PTDI determined by JECFA for Cr. However, the MRL of $5 \mu \mathrm{g} / \mathrm{kg}$ bw/day was derived for intermediate-duration oral exposure (15-364 days) to $\mathrm{Cr}$ [13]. Therefore, our results are within the limits established by the MRL.

In Tables 7 and 8 , the $H Q$ values of $\mathrm{Cr}$ for adults in all roasted meats were less than 1 . There are potential effects caused by $\mathrm{Cr}$ unbalance in adults, such as bronchial asthma, lung, and nasal ulcers and cancers, skin allergies, reproductive and developmental problems, and carcinogenic [63]. With the $H Q$ results below 1, the consumption of these preparations may fall into the other side of $\mathrm{Cr}$ intake, being an essential nutrient for regular protein, fat, and carbohydrate metabolism [64] and critical to health and nutrition. 


\subsubsection{Copper $(\mathrm{Cu})$}

The values of the EDI of $\mathrm{Cu}$ due to the ingestion of roasted beef, pork, lamb, and chicken (Tables 7 and 8) with electric grill, wood, and coals varied between 0.8487 and $2.0856 \mu \mathrm{g} / \mathrm{kg} \mathrm{bw} /$ day, 0.0158 to $0.0862 \mu \mathrm{g} / \mathrm{kg}$ bw/day, 0.0469 and $0.3285 \mu \mathrm{g} / \mathrm{kg}$ bw/day, and 0.0095 and $0.0320 \mu \mathrm{g} / \mathrm{kg}$ bw/day, respectively. According to the JECFA, the value of PTDI suggested for $\mathrm{Cu}$ is $500 \mu \mathrm{g} / \mathrm{kg} \mathrm{bw} / \mathrm{day}$, and the values of the MRL derived for intermediate-duration oral exposure (15-364 days) for the $\mathrm{Cu}$ is $10 \mu \mathrm{g} / \mathrm{kg} / \mathrm{day}[13,65]$. Thus, the EDI values of $\mathrm{Cu}$ in all samples of meat were below the permissible limits (PTDI and MRL). Therefore, the consumption of one portion of meats roasted does not confer a risk of adverse health effects for adults. However, the continued ingestion of this roasted meat can cause toxicity. Increased meat-eating increases $\mathrm{Cu}$ absorption and overall $\mathrm{Cu}$ exposure. $\mathrm{Cu}$ intake is a significant risk factor for Alzheimer's disease [66]. Nonetheless, when consumed within the safe limits, $\mathrm{Cu}$ plays several roles in human metabolism, acting as a cofactor and structural constituent of enzymes [67].

\subsubsection{Iron $(\mathrm{Fe})$}

Concerning the roast beef meat with electric grill, wood, and coals, the value of EDI of Fe ranged from 30.4534 to $78.6208 \mu \mathrm{g} / \mathrm{kg}$ bw/day. The EDI of Fe due to consumption of roasted pork loin with electric grill, wood fire, and coals ranged from 0.9872 to $1.4644 \mu \mathrm{g} / \mathrm{kg}$ bw/day (Table 7). The intake of chicken breast with electric grill, wood fire, and coals provided EDI values for Fe from 3.6083 to $10.0896 \mu \mathrm{g} / \mathrm{kg} \mathrm{bw} /$ day. Moreover, the EDI of Fe due to intake for roasted lamb shank with electric grill, wood fire, and coals varied from 0.3935 to $0.8195 \mu \mathrm{g} / \mathrm{kg}$ bw/day (Table 8 ). The value of PTDI of Fe established by the JECFA is $800 \mu \mathrm{g} / \mathrm{kg}$ bw/day [68], but there are no values of the MRL set for Fe. From a comparison of the values EDI with those proposed by PTDI, it is possible to conclude that the EDI value for Fe is below the PTDI value. The high consumption of red meat is the leading cause of the increase in the risk of non-communicable diseases, type II diabetes, and cardiovascular disease. This hazard could be related to Fe intake [69,70]. However, the $H Q$ of Fe for adults in all roast meats types was less than 1 (Tables 7 and 8). In this way, roasted meats do not represent a risk for adverse health effects for adults. Sufficient data to define a safe lower limit for toxic Fe ingestions are not available. Fe deficiency is the most prevalent worldwide [71]; therefore, the consumption of appropriate amounts of this metal in consort with a balanced diet is recommended.

\subsubsection{Magnesium $(\mathrm{Mg})$}

The values of the EDI of $\mathrm{Mg}$ due to the ingestion of roasted beef meat with electric grill, wood, and coals varied in a range from 278.0439 to $334.2648 \mu \mathrm{g} / \mathrm{kg}$ bw/day. EDI values due to the consumption of roasted pork loin with electric grill, wood fire, and coals varied from 24.9888 to $44.5072 \mu \mathrm{g} / \mathrm{kg}$ bw/day (Table 7). The observed range of EDI of Mg in the current study for roasted chicken breast with electric grill, wood fire, and coals is between 173.7921 and $218.3639 \mu \mathrm{g} / \mathrm{kg}$ bw/day. Moreover, the EDI of $\mathrm{Mg}$ due to intake for roasted lamb shank with electric grill, wood fire, and coals varied from 3.2890 to $4.1095 \mu \mathrm{g} / \mathrm{kg} \mathrm{bw} /$ day (Table 8). There are no values established by the JECFA (PTDI) and the MRL for $\mathrm{Mg}$. However, the UL level of Mg for males/females (19-70 years old) is $350 \mathrm{mg} /$ day [14]. The tolerable upper intake level is the highest level of daily nutrient intake that is likely to pose no risk of adverse health effects in almost all individuals. Thus, the values EDI of $\mathrm{Mg}$ in all samples of meat were below the permissible limits by UL.

The $H Q$ values of $\mathrm{Mg}$ for adults in all roasted-meat-types consumption for adults were less than 1 (Tables 7 and 8). Therefore, the presence of $\mathrm{Mg}$ in meat does not cause any harm to health. To date, there are no studies of $\mathrm{Mg}$ intoxication due to food intake. However, substantial doses of Mg-containing laxatives and antacids have been associated with $\mathrm{Mg}$ toxicity because of excessive oral consumption [72]. 


\subsubsection{Manganese (Mn)}

The values of the EDI of Mn due to the ingestion of roasted beef, pork, lamb, and chicken with electric grill, wood, and coals ranged from 0.0036 to $0.08667 \mu \mathrm{g} / \mathrm{kg}$ bw/day, 0.0024 to $0.1214 \mu \mathrm{g} / \mathrm{kg}$ bw/day, 0.0521 to $0.2868 \mu \mathrm{g} / \mathrm{kg}$ bw/day, and 0.0002 to $0.0063 \mu \mathrm{g} / \mathrm{kg}$ bw/day, respectively (Tables 7 and 8). According to the JECFA, the value of PTDI suggested for Mn is $140 \mu \mathrm{g} / \mathrm{kg} \mathrm{bw} /$ day [6]. There are no values of the MRL derived for oral exposure to the Mn. The EDI values of $\mathrm{Mn}$ in all samples of meat were below the established limit by PTDI, indicating a safe consumption with these treatments concerning this metal.

In all meats roasted with electric grill, wood and coal, Mn $H Q$ values for adults were below 1 (Tables 7 and 8); it represents negligible hazard when assessing hazards by severity, thus corroborating the findings of the EDI values. No evidence shows Mn toxicity from high dietary Mn intakes due to meat and other foods. However, people who consume $28 \mathrm{mg} / \mathrm{L}$ of water containing high levels of elements such as Mn can develop toxicity [73]. Although $\mathrm{Mn}$ is an essential nutrient, especially regarding the reduction of oxidative stress, both Mn deficiency or overload is rare, whereas the excess is usually caused by environmental exposure [74,75].

\subsubsection{Molybdenum (Mo)}

The EDI of Mo due to the consumption of roasted beef meat with electric grill, wood fire, and coals and roasted lamb shank with wood and coals varied from 0.4966 to $0.6591 \mu \mathrm{g} / \mathrm{kg} \mathrm{bw} /$ day and from 0.0077 to $0.010 \mu \mathrm{g} / \mathrm{kg} \mathrm{bw} /$ day (Tables 7 and 8). There are no values established by the JECFA (PTDI) for Mo. However, the MRL is $60 \mu \mathrm{g} / \mathrm{kg} /$ day [13]. Therefore, the EDI of Mo due to the ingestion of the roasted meat is below the MRL value.

The $H Q$ of Mo for adults in all roasted meat types was inferior to 1 . The toxicity of Mo compounds is low in humans. Currently, clinical data are scarce to allow definitive conclusions about the effects of Mo toxicity due to Mo supplementation and foods [76].

\subsubsection{Nickel (Ni)}

The Ni EDI concentration was below the limit of detection in all raw and cooked samples of beef, pork, lamb, and chicken, except for the electric grill samples. For all roast-meat types in Tables 7 and 8 , the $H Q$ values of $\mathrm{Ni}$ for adults were below 1, so roasted meats with these fuels do not represent a risk of adverse health effects for adults. A caveat is in relation to the stainless steel grill used during the preparation. Although this is not considered a dangerous material and has great application for hygiene and food safety, there are records of dermatitis resulting from $\mathrm{Ni}$ in the diet, as demonstrated in previous studies [77]. A dose of only $0.067 \mathrm{mg}$ of $\mathrm{Ni}$ has been associated with cutaneous reactions in $40 \%$ of participants with Ni sensitivity $[77,78]$. Our result showed Ni values higher than those $[77,78]$; therefore, leached $\mathrm{Ni}$ can be relevant for highly sensitive patients.

\subsubsection{Vanadium (V)}

The $E D I$ of $\mathrm{V}$ in all meat types varied from 0.0009 to 0.9751 (Tables 7 and 8 ). There is not a set value of PTDI for V established by the JECFA, but there are values of the MRL derived for intermediate-duration oral exposure, which is $100 \mu \mathrm{g} / \mathrm{kg} / \mathrm{day}$ [13]. From the comparison, values EDI with those proposed by $\mathrm{MRL}$, it is viable to conclude that the EDI value for $\mathrm{V}$ in Tables 7 and 8 are below the MRL value.

For all roast-meat types in Tables 7 and 8 , the $H Q$ values of $V$ for adults were below 1 , so roasted meats with these fuels do not represent a risk of adverse health effects for adults. Food and water are the primary sources of exposure to $\mathrm{V}$ for the general population. Symptoms of $\mathrm{V}$ toxicity vary with chemical form and route of absorption. Stomach cramps were reported in a study of people taking about $13 \mathrm{mg} \mathrm{V/day} \mathrm{[79],} \mathrm{and} \mathrm{its} \mathrm{intake} \mathrm{is} \mathrm{not} \mathrm{considered} \mathrm{to} \mathrm{be} \mathrm{essential} \mathrm{[80].}$ 


\subsubsection{Zinc $(\mathrm{Zn})$}

The values of the EDI of $\mathrm{Zn}$ from the ingestion of roast beef meat with electric grill, wood, and coals varied in a range between 42.1905 and $104.0453 \mu \mathrm{g} / \mathrm{kg}$ bw/day. The EDI, due to the consumption of roasted pork loin with electric grill, wood fire, and coals, varied from 1.8251 to $2.5694 \mu \mathrm{g} / \mathrm{kg}$ bw/day (Table 7). The observed range of EDI of $\mathrm{Zn}$ in the current study for roasted chicken breast with electric grill, wood fire, and coals was found to be between 4.5521 and $8.4941 \mu \mathrm{g} / \mathrm{kg} \mathrm{bw} /$ day. The EDI of $\mathrm{Zn}$ due to intake for roasted lamb shank with electric grill, wood fire, and coals varied from 0.5234 to $0.9273 \mu \mathrm{g} / \mathrm{kg}$ bw/day (Table 8). The value of PTDI established by the JECFA for Zn is $300 \mu \mathrm{g} / \mathrm{kg} \mathrm{bw} /$ day [65], and the values of the MRL derived for intermediate-duration oral exposure (15-364 days) for the $\mathrm{Zn}$ is $300 \mu \mathrm{g} / \mathrm{kg} /$ day [13]. Thus, the EDI values of $\mathrm{Zn}$ in all samples of meat were below the permissible limits (PTDI and MRL).

The $H Q$ values of $Z n$ for adults are below 1 in all examples of roasted meat. The impact on human health by intoxication with $\mathrm{Zn}$ is a rare event, as $\mathrm{Zn}$ has low toxicity [81]. Excessive amounts of $\mathrm{Zn}$ in the body may cause harmful effects to the kidneys, liver, spleen, brain, and heart [82,83]; nonetheless, $\mathrm{Zn}$ essentiality in unquestionable, as $\mathrm{Zn}$ participates in cellular function, differentiation, division, and growth [84].

\section{Conclusions}

The present study showed that there are statistical differences in the contents of major $(\mathrm{Mg})$ and trace elements ( $\mathrm{Al}, \mathrm{As}, \mathrm{Cr}, \mathrm{Cu}, \mathrm{Fe}, \mathrm{Mn}, \mathrm{Mo}, \mathrm{V}$, and $\mathrm{Zn}$ ) in raw meats, meats roasted with an electric grill with electric grill, and roasted meats on barbecues grill, using different fuels.

The concentrations of $\mathrm{Al}, \mathrm{Cr}, \mathrm{Cu}$, and $\mathrm{Fe}$ in raw meats were below the values obtained by other countries. However, high levels of As in the raw beef topside, raw pork loin, raw chicken breast, and $\mathrm{Mg}, \mathrm{V}$, and $\mathrm{Zn}$ in all raw meats were quantified in this study. The content of $\mathrm{Cu}, \mathrm{Cr}$, and As were higher in meats roasted using wood. On the other hand, there was an increase in the values of $\mathrm{V}, \mathrm{Al}$, and Fe when the meat was roasted using charcoal.

The concentration of $\mathrm{Ni}$ and $\mathrm{Cd}$ was high when the meats were roasted using an electric grill. In fact, the material from which electric grills are made can contaminate meat. Mo levels were quantified in the raw and roasted leg of lamb shank with the electric grill, and in the roasted beef and leg of lamb shank, using different fuels. On the other hand, the variations in the concentrations of $\mathrm{Mg}$, $\mathrm{Mn}$, and $\mathrm{Mo}$ in the roasted meat are due to the presence of particles and gases from wood and coal. The levels of all measured elements in raw meats and in electric grilled meats are usually lower than those in the roasted meats with coal and wood, except for $\mathrm{Ni}$ and $\mathrm{Cd}$.

There are no values established by MRL for $\mathrm{Fe}, \mathrm{Mg}, \mathrm{Ni}$, and $\mathrm{Mn}$. In addition, there is no value of PTDI suggested by JECFA for $\mathrm{Cr}, \mathrm{Mo}, \mathrm{Mg}$, and $\mathrm{V}$. The EDI of $\mathrm{Al}, \mathrm{Cu}$, and $\mathrm{Zn}$ are below the limit of JECFA and MRL reference levels. However, the EDI values of $\mathrm{Cr}, \mathrm{Mo}$, and $\mathrm{V}$ found in this study did not exceed the MRL standard. The EDI values of Fe and Mn are below the PTDI value. The EDI values of $\mathrm{Mg}$ in all samples of meat were below the permissible limits by UL. However, EDI values of As in some roasted meats are above of EFSA and JECFA limits.

Samples of roast chicken breast with wood fire and coal presented $H Q$ values of $\mathrm{Al}$ and As for adults above 1 . Moreover, $H Q$ values of $\mathrm{Cr}, \mathrm{Cu}, \mathrm{Fe}, \mathrm{Mn}, \mathrm{Mg}, \mathrm{Mo}, \mathrm{V}$, and $\mathrm{Zn}$ for adults in all roasted meats were less than 1 . According to the Agency for Toxic Substances and Disease Registry, the effects of exposure to any hazardous substance depend on the dose and principally the duration.

Although $H Q$ is less than 1, the health hazards associated with the use of woods and charcoal are of significant concern, and smoke associated with this meat-roasting process represents a significant source of contaminants and can add to the ingestion source. Levels of $\mathrm{Cd}$ and Ni were detected in the meats prepared in the electric grill, in opposition to the meats roasted with different types of woods and coals, which raises a concern on the day-to-day use of this equipment present in several households.

Finally, the metals and metalloids emitted by the combustion of coal or wood combustion in restaurants or domestic kitchens, wood stoves, and barbecue grills should be investigated, 
considering the risk to children, the elderly, and pregnant women, especially. High exposures to a long-term contaminant may cause damage to health.

Supplementary Materials: The following are available online at http://www.mdpi.com/1660-4601/17/18/6737/s1. Figure S1: Comparison of mineral concentration in raw and roasted beef, pork, lamb and chicken using different fuels. (a) Aluminum, (b) Arsenium, (c) Chromium, (d) Copper, (e) Iron, (f) Magnesium, (g) Manganese, (h) Molybdenum, (i) Vanadium, (j) Zinc, (k) Cadmium, (l) Nickel.

Author Contributions: Conceptualization, L.C.S.L. and E.F.d.S.; methodology, E.S.d.P.M. and L.C.S.L.; writing - original draft preparation, L.C.S.L. and V.A.d.N.; writing—review and editing, V.A.d.N. and D.G.A.; supervision, V.A.d.N. All authors have read and agreed to the published version of the manuscript.

Funding: This research was supported by the National Council for Scientific and Technological Development $(\mathrm{CNPq})$, Brazil. This study was financed in part by the Coordenação de Aperfeiçoamento de Pessoal de Nível Superior-Brasil-(CAPES)—Finance Code 001.

Acknowledgments: We would like to acknowledge the Federal University of Mato Grosso do Sul (UFMS) for financial support.

Conflicts of Interest: The authors declare no conflict of interest.

\section{References}

1. FAO. Agriculture and Consumer Protection Department Animal Production and Health. Available online: http://www.fao.org/ag/againfo/themes/en/meat/backgr_sources.html (accessed on 16 April 2020).

2. Ortega-Barrales, P.; Fernández-de Córdova, M.L. Meat. In Handbook of Mineral Elements in Food, 1st ed.; De la Guardia, M., Garrigues, S., Eds.; John Wiley \& Sons: Chichester, UK, 2015; p. 599.

3. Cabrera, M.C.; Ramos, A.; Saadoun, A.; Brito, G. Selenium, copper, zinc, iron and manganese content of seven meat cuts from Hereford and Braford steers fed pasture in Uruguay. Meat Sci. 2010, 84, 518-528. [CrossRef] [PubMed]

4. Ramos, A.; Cabrera, M.C.; Saadoun, A. Bioaccessibility of $\mathrm{Se}, \mathrm{Cu}, \mathrm{Zn}, \mathrm{Mn}$ and Fe, and heme iron content in unaged and aged meat of Hereford and Braford steers fed pasture. Meat Sci. 2012, 91, 116-124. [CrossRef] [PubMed]

5. European Commission. Commission Regulation (EC) $\mathrm{n}^{\mathrm{o}}$ 1881/2006 Setting maximum levels for certain contaminants in foodstuffs. Off. J. Eur. Union. 2006, 364, 5-24.

6. JECFA WHO. Summary and Conclusions of the 61st Meeting of the Joint FAO/WHO Expert Committee on Food Additives; JECFA WHO: Rome, Italy, 2003.

7. JECFA WHO. Evaluation of Certain Food Additives and Contaminants; Technical Report Series, 72nd; JECFA WHO: Rome, Italy, 2010.

8. EFSA Scientific Committee. Update: Use of benchmark dose approach in risk assessment. EFSA J. 2017, 15, e04658.

9. Onsanit, S.; Ke, C.; Wang, X.; Wang, K.J.; Wang, W.X. Trace elements in two marine fish cultured in fish cages in Fujian province, China. Environ. Pollut. 2010, 158, 1334-1342. [CrossRef] [PubMed]

10. Rodríguez-Hernández, Á.; Zumbado, M.; Henríquez-Hernández, L.A.; Boada, L.D.; Luzardo, O.P. Dietary intake of essential, toxic, and potentially toxic elements from mussels (Mytilus spp.) in the Spanish population: A nutritional assessment. Nutrients 2019, 11, 864. [CrossRef]

11. Miclean, M.; Cadar, O.; Levei, E.A.; Roman, R.; Ozunu, A.; Levei, L. Metal (Pb, Cu, Cd, and Zn) Transfer along Food Chain and Health Risk Assessment through Raw Milk Consumption from Free-Range Cows. Int. J. Environ. Res. Public Health 2019, 16, 4064. [CrossRef]

12. Zhou, H.; Yang, W.T.; Zhou, X.; Liu, L.; Gu, J.F.; Wang, W.L.; Liao, B.H. Accumulation of Heavy Metals in Vegetable Species Planted in Contaminated Soils and the Health Risk Assessment. Int. J. Environ. Res. Public Health 2016, 13, 289. [CrossRef]

13. ATSDR Minimal Risk Levels (MRLs) for Hazardous Substances. Available online: https://www.atsdr.cdc. gov/mrls/mrllist.asp (accessed on 29 April 2020).

14. IOM Food and Nutrition Board. Dietary Reference Intakes: The Essential Guide to Nutrient Requirements. Available online: https://www.nal.usda.gov/sites/default/files/fnic_uploads/DRIEssentialGuideNutReq.pdf (accessed on 10 April 2020). 
15. Joyce, K.; Emikpe, B.O.; Asare, D.A.; Asenso, T.N.; Yeboah, R.; Jarikre, T.A.; Jagun, J.A. Effects of different cooking methods on heavy metals level in fresh and smoked game meat. Int. J. Food Process. Technol. 2016, 7, 9-11. [CrossRef]

16. Lopes, M.V.; Korn, M.; Pereira, M.G.; de Santana, E.P.; de Oliveira, F.S.; Korn, M.D.G. Cadmium and lead retention in fresh and rotten red meat. J. Brazil Chem. Soc. 2007, 18, 703-708. [CrossRef]

17. Mehta, B.M. Nutritional and Toxicological Aspects of the Chemical Changes of Food Components and Nutrients during Heating and Cooking. In Handbook of Food Chemistry; Cheung, P., Mehta, B., Eds.; Springer: GenBerlin/Heidelberg, Germany, 2015; pp. 897-936. [CrossRef]

18. Kabir, E.; Kim, K.-H.; Yoon, H.O. Trace metal contents in barbeque (BBQ) charcoal products. J. Hazard. Mater. 2011, 185, 1418-1424. [CrossRef] [PubMed]

19. Sharp, A.; Turner, A. Concentrations and bioaccessibilities of trace elements in barbecue charcoals. J. Hazard. Mater. 2013, 262, 620-626. [CrossRef] [PubMed]

20. Susaya, J.; Kim, K.H.; Ahn, J.W.; Jung, M.C.; Kang, C.H. BBQ charcoal combustion as an important source of trace metal exposure to humans. J. Hazard. Mater. 2010, 176, 932-937. [CrossRef] [PubMed]

21. Taner, S.; Pekey, B.; Pekey, H. Fine particulate matter in the indoor air of barbeque restaurants: Elemental compositions, sources and health risks. Sci. Total Environ. 2013, 454-455, 79-87. [CrossRef] [PubMed]

22. Ferrarini, S.F.; dos Santos, H.S.; Miranda, L.G.; Azevedo, C.M.N.; Maia, S.M.; Pires, M. Decontamination of CCA-treated eucalyptus wood waste by acid leaching. Waste Manag. 2016, 49, 253-262. [CrossRef] [PubMed]

23. Lansbury, N.H.; Beder, S. Treated Timber, Ticking Time-Bomb. The Need for a Precautionary Approach to the Use of Copper Chrome Arsenate (CCA) as a Timber Preservative; University of Wollongong: Wollongong, NSW, Australia, 2005.

24. Ohgami, N.; Yamanoshita, O.; Thang, N.D.; Yajima, I.; Nakano, C.; Wenting, W.; Kato, M. Carcinogenic risk of chromium, copper and arsenic in CCA-treated wood. Environ. Pollut. 2015, 206, 456-460. [CrossRef] [PubMed]

25. Shiau, R.J.; Smith, R.L.; Avellar, B. Effects of steam explosion processing and organic acids on CCA removal from treated wood waste. Wood Sci. Technol. 2000, 34, 377-388. [CrossRef]

26. Goran, G.V.; Tudoreanu, L.; Rotaru, E.; Crivineanu, V. Comparative study of mineral composition of beef steak and pork chops depending on the thermal preparation method. Meat Sci. 2016, 118, 117-121. [CrossRef]

27. Higuera, J.M.; Silva, A.B.S.; Nogueira, A.R.A. Multi-Energy Calibration: A Practical Method for Determination of Macro and Micro Nutrients in Meat by ICP OES. J. Brazil Chem. Soc. 2019, 30, 2575-2581. [CrossRef]

28. Gerber, N.; Brogioli, R.; Hattendorf, B.; Scheeder, M.R.L.; Wenk, C.; Günther, D. Variability of selected trace elements of different meat cuts determined by ICP-MS and DRC-ICPMS. Animal 2009, 3, 166-172. [CrossRef]

29. Abou-Arab, A.A.K. Heavy metal contents in Egyptian meat and the role of detergent washing on their levels. Food Chem. Toxicol. 2001, 39, 593-599. [CrossRef]

30. Bou, R.; Guardiola, F.; Padró, A.; Pelfort, E.; Codony, R. Validation of mineralisation procedures for the determination of selenium, zinc, iron and copper in chicken meat and feed samples by ICP-AES and ICP-MS. J. Anal. At. Spectrom. 2004, 19, 1361-1369. [CrossRef]

31. Long, G.L.; Winefordner, J.D. Limit of detection. A closer look at the IUPAC definition. Anal. Chem. 1983, 55, 712A-724A.

32. IBGE. Pesquisa de Orçamento Familiar (POF) 2008-2009: Análise do Consumo Alimentar Pessoal no Brasil; IBGE: Rio de Janeiro, Brazil, 2011; p. 150.

33. USEPA IRIS Program Information about the Integrated Risk Information System: Chronic Oral Reference Dose (RfD). Available online: https://cfpub.epa.gov/ncea/iris/search/ (accessed on 29 April 2020).

34. González-Weller, D.; Gutiérrez, A.J.; Rubio, C.; Revert, C.; Hardisson, A. Dietary intake of aluminum in a Spanish population (Canary Islands). J. Agric. Food Chem. 2010, 58, 10452-10457. [CrossRef]

35. Leblanc, J.C.; Guérin, T.; Noël, L.; Calamassi-Tran, G.; Volatier, J.L.; Verger, P. Dietary exposure estimates of 18 elements from the 1st French Total Diet Study. Food Addit. Contam. 2005, 22, 624-641. [CrossRef] [PubMed]

36. Mohamed, H.; Haris, P.I.; Brima, E.I. Estimated dietary intakes of toxic elements from four staple foods in Najran city, Saudi Arabia. Int. J. Environ. Res. Public Health 2017, 14, 1575. [CrossRef]

37. Miedico, O.; Iammarino, M.; Tarallo, M.; Chiaravalle, A.E. Application of inductively coupled plasma-mass spectrometry for trace element characterisation of equine meats. Int. J. Food Prop. 2017, 20, 2888-2900. [CrossRef] 
38. Chen, S.S.; Lin, Y.W.; Kao, Y.M.; Shih, Y.C. Trace elements and heavy metals in poultry and livestock meat in Taiwan. Food Addit. Contam. Part B 2013, 6, 231-236. [CrossRef]

39. Diaconescu, C.; Fantaneru, G.; Urdes, L.; Vidu, L.; Vasile, B.; Stefan, D. Influence of cooking methods over the heavy metal and lipid content of fish meat. Rom. Biotechnol. Lett. 2013, 18, 8279.

40. Kartal, S.N. Removal of copper, chromium, and arsenic from CCA-C treated wood by EDTA extraction. J. Waste Manag. 2003, 23, 537-546. [CrossRef]

41. Guarneri, F.; Costa, C.; Cannavò, S.P.; Catania, S.; Bua, G.D.; Fenga, C.; Dugo, G. Release of nickel and chromium in common foods during cooking in 18/10 (grade 316) stainless steel pots. Contact Dermat. 2016, 76, 40-48. [CrossRef] [PubMed]

42. Kamerud, K.L.; Hobbie, K.A.; Anderson, K.A.J. Stainless steel leaches nickel and chromium into foods during cooking. J. Agric. Food Chem. 2013, 61, 9495-9501. [CrossRef]

43. Ihedioha, J.N.; Okoye, C.O.; Onyechi, U.A. Health risk assessment of zinc, chromium, and nickel from cow meat consumption in an urban Nigerian population. Int. J. Occup. Environ. Health 2014, 20, 281-288. [CrossRef]

44. Dan, Z.G.; Ni, H.W.; Xu, B.F.; Xiong, J.; Xiong, P.Y. Microstructure and antibacterial properties of AISI 420 stainless steel implanted by copper ions. Thin Solid Films 2005, 492, 93-100. [CrossRef]

45. Alturiqi, A.S.; Albedair, L.A. Evaluation of some heavy metals in certain fish, meat and meat products in Saudi Arabian markets. Egypt. J. Aquat. Res. 2012, 38, 45-49. [CrossRef]

46. Ikem, A.; Shanks, B.; Caldwell, J.; Garth, J.; Ahuja, S. Estimating the daily intake of essential and nonessential elements from lamb $\mathrm{m}$. longissimus thoracis et lumborum consumed by the population in Missouri (United States). J. Food Compos. Anal. 2015, 40, 126-135. [CrossRef]

47. Alegría, A.; Barberá, R.; Lagarda, M.J.; Farré, R. Minerals and trace elements. In Handbook of Muscle Foods Analysis; Nollet, L.M.L., Toldrá, F., Eds.; Taylor \& Francis Group: Boca Raton, FL, USA, 2009; pp. 441-463.

48. Gadzhieva, A. Iron and Magnesium Determination in Meat using Flame Atomic Absorption Spectroscopy. Available online: https:/assets.thermofisher.com/TFS-Assets/CMD/Application-Notes/AN-43190-AAS-IronMagnesium-Meat-AN43190-EN.pdf (accessed on 29 April 2020).

49. Sacco, D.; Brescia, M.A.; Buccolieri, A.; Jambrenghi, A.C. Geographical origin and breed discrimination of Apulian lamb meat samples by means of analytical and spectroscopic determinations. Meat Sci. 2005, 71, 542-548. [CrossRef]

50. German Federal Institute for Risk Assessment. Bundesinstitut für Risikobewertung: Freisetzung von Metallen aus emaillierten Grillrosten: Einige geben zu viel ab. Stellungnahme Nr. 024/2018 des BfR vom 26. Juli 2018. Available online: https://www.openagrar.de/receive/openagrar_mods_00040860 (accessed on 30 August 2020).

51. Byrne, A.R.; Kosta, L. Vanadium in foods and in human body fluids and tissues. Sci. Total Environ. 1978, 10, 17-30. [CrossRef]

52. Ambushe, A.A.; Hlongwane, M.M.; McCrindle, R.I.; McCrindle, C.M.E. Assessment of levels of V, Cr, Mn, Sr, $\mathrm{Cd}, \mathrm{Pb}$ and $\mathrm{U}$ in bovine meat. S. Afr. J. Chem. 2012, 65, 159-164.

53. Centre for Food Safety Food and Environmental Hygiene Department. The First Hong Kong Total Diet Study: Metallic Contaminant. Available online: https://www.cfs.gov.hk/english/programme/programme_ firm/files/Report_on_1st_HKTDS_Metallic_Contaminants.pdf (accessed on 27 April 2020).

54. Iwegbue, C.M.A.; Nwajei, G.E.; Iyoha, E.H. Heavy metal residues of chicken meat and gizzard and turkey meat consumed in southern Nigeria. Bulg. J. Vet. Med. 2008, 11, 275-280.

55. Abdelbasset, C.; Rabia, E.; Abdallah, B.; Boubker, N.; AbdelKhalid, E. Distribution of trace elements and heavy metals in liver, lung, meat, heart and kidney of cattle, sheep, camel and equine slaughtered in Casablanca city-Morocco. IJSER 2014, 5, 294-303.

56. Rogge, W.F.; Hildemann, L.M.; Mazurek, M.A.; Cass, G.R.; Simoneit, B.R.T. Sources of fine organic aerosol. 1. Charbroilers and meat cooking operations. Environ. Sci. Technol. 1991, 25, 1112-1125. [CrossRef]

57. JECFA WHO. Evaluation of Certain Food Additives and Contaminants; Technical Report Series, 74th; JECFA WHO: Rome, Italy, 2011; Volume 966, pp. 7-17.

58. Tomljenovic, L. Aluminum and Alzheimer's disease: After a century of controversy, is there a plausible link? J. Alzheimers Dis. 2011, 23, 567-598. [CrossRef] [PubMed]

59. Lidsky, T.I. Is the Aluminum Hypothesis dead? J. Occup. Environ. Med. 2014, 56, S73. [CrossRef] [PubMed] 
60. EFSA. Scientific opinion of the panel on contaminants in the food chain. Scientific opinion on arsenic in food. EFSA J. 2009, 7, 1351. [CrossRef]

61. WHO. Arsenic. Available online: https://www.who.int/news-room/fact-sheets/detail/arsenic (accessed on 13 May 2020).

62. Tolins, M.; Ruchirawat, M.; Landrigan, P. The developmental neurotoxicity of arsenic: Cognitive and behavioral consequences of early life exposure. Ann. Glob. Health 2014, 80, 303-314. [CrossRef]

63. Shekhawat, K.; Chatterjee, S.; Joshi, B. Chromium Toxicity and its Health Hazards. Int. J. Adv. Res. 2015, 3, 167-172.

64. Swaroop, A.; Bagchi, M.; Preuss, H.G.; Zafra-Stone, S.; Ahmad, T.; Bagchi, D. Benefits of chromium (III) complexes in animal and human health. In The Nutritional Biochemistry of Chromium (III); Elsevier: Amsterdam, The Netherlands, 2019; pp. 251-278.

65. JECFA WHO. Evaluation of Certain Food Additives and Contaminants; Technical Report, 26th; JECFA WHO: Geneva, Switzerland, 1982.

66. Brewer, G.J. Copper-2 Ingestion, Plus Increased Meat Eating Leading to Increased Copper Absorption, Are Major Factors Behind the Current Epidemic of Alzheimer's Disease. Nutrients 2016, 8, 194. [CrossRef]

67. Stern, B.R. Essentiality and Toxicity in Copper Health Risk Assessment: Overview, Update and Regulatory Considerations. J. Toxicol. Environ. Health Sci. 2010, 73 Pt A, 114-127. [CrossRef]

68. JECFA WHO. Evaluation of Certain Food Additives and Contaminants; Technical Report, 27th; JECFA WHO: Geneva, Switzerland, 1983.

69. Hur, S.J.; Yoon, Y.; Jo, C.; Jeong, J.Y.; Lee, K.T. Effect of Dietary Red Meat on Colorectal Cancer Risk: A Review. Compr. Rev. Food Sci. F. 2019, 18, 1812-1824. [CrossRef]

70. Czerwonka, M.; Tokarz, A. Iron in red meat-friend or foe. Meat Sci. 2017, 123, 157-165. [CrossRef] [PubMed]

71. Swanson, C.A. Iron intake and regulation: Implications for iron deficiency and iron overload. Alcohol 2003, 30, 99-102. [CrossRef]

72. Costello, R.; Wallace, T.C.; Rosanoff, A. Magnesium. Adv. Nutr. 2016, 7, 199-201. [CrossRef] [PubMed]

73. Kondakis, X.G.; Makris, N.; Leotsinidis, M.; Prinou, M.; Papapetropoulos, T. Possible health effects of high manganese concentration in drinking water. Arch. Environ. Health 1989, 44, 175-178. [CrossRef]

74. Li, L.; Yang, X. The Essential Element Manganese, Oxidative Stress, and Metabolic Diseases: Links and Interactions. Oxidative Med. Cell. Longev. 2018. [CrossRef]

75. Martins, A.C.; Krum, B.N.; Queirós, L.; Tinkov, A.A.; Skalny, A.V.; Bowman, A.B.; Aschner, M. Manganese in the Diet: Bioaccessibility, Adequate Intake, and Neurotoxicological Effects. J. Agric. Food Chem. 2020. [CrossRef]

76. Momčilovic, B. Acute human molybdenum toxicity. Arh. Hig. Radr. Toksikol. 1999, 50, $289-297$.

77. Zirwas, M.J.; Molenda, M.A. Dietary nickel as a cause of systemic contact dermatitis. J. Clin. Aesthet. Dermatol. 2009, 2, 39-43.

78. Jensen, C.S.; Menne, T.; Lisby, S.; Kristiansen, J.; Veien, N.K. Experimental systemic contact dermatitis from nickel: A dose-response study. Contact Dermat. 2003, 49, 124-132. [CrossRef]

79. ATSDR Toxicological Profile for Vanadium. Available online: https://www.atsdr.cdc.gov/ToxProfiles/TP.asp? $\mathrm{id}=276 \& \mathrm{tid}=50$ (accessed on 27 April 2020).

80. Vincent, J.B.; Neggers, Y.; McClung, J. Chapter 56-Roles of Chromium (III), Vanadium, Iron, and Zinc in Sports Nutrition. In Nutrition and Enhanced Sports Performance, 2nd ed.; Bagchi, D., Nair, S., Sen, C.K., Eds.; Academic Press: Cambridge, MA, USA, 2019; pp. 653-664.

81. Plum, L.M.; Rink, L.; Haase, H. The essential toxin: Impact of zinc on human health. Int. J. Environ. Res. Public Health 2010, 7, 1342-1365. [CrossRef]

82. Paun, S.; Tudosie, M.; Petris, R.; Macovei, R. The effects of zinc on human body, including on renal failure and renal transplantation. J. Med. Life. 2012, 5, 137. [PubMed]

83. Nriagu, J. Zinc Toxicity in Humans. Encycl. Environ. Health 2011, 801-807. [CrossRef]

84. Chasapis, C.T.; Ntoupa, P.-S.A.; Spiliopoulou, C.A.; Stefanidou, M.E. Recent aspects of the effects of zinc on human health. Arch. Toxicol. 2020, 94, 1443-1460. [CrossRef] [PubMed] 